Revista de Derecho de la Pontificia Universidad Católica de Valparaíso XXXVI (Valparaíso, Chile, 2011, $1^{\text {er }}$ Semestre)

[pp. 495 - 529]

\title{
Discrecionalidad del Ministerio Público Y OBJETO DEL JUICIO ABREVIADO*
}

["The Discretional Character of the Public Prosecutor's Office and the Purpose of the Summary Trial”]

\section{Manuel Rodríguez VegA**}

\begin{abstract}
Resumen
Es posible identificar normas procesales y sustantivas en la litigación civil y comercial internacional donde asumen especial importancia la "justicia procesal” o "debido proceso". El sistema procesal civil nacional no tiene un regimen simétrico, moderno y coherente de regulación de la litigación civil nacional e internacional. Hay normas aisladas que regulan esta última, especialmente en tanto arbitraje comercial internacional.

Palabras Clave

Ejecución - Circulación sentencias extranjeras -Debido proceso.
\end{abstract}

\begin{abstract}
Procedural and substantive rules can be recognized in international civil and commercial litigation where "procedural justice" or "due process" gain special importance. The national civil procedure system does not have a symmetric, modern and coherent national and international civil litigation regulation regime. There are isolated norms ruling the latter, especially in terms of international commercial arbitration.

\section{KEYWORDS}

Execution - Circulation of foreign judgements - Due process.
\end{abstract}

[REcibido el 28 de marzo y APROBADo el 10 de junio de 2011].

* El presente trabajo surgió a partir del curso "Seminario habilitante de investigación", en el Programa de Doctorado en Derecho de la Universidad de Chile.

** Magíster en Derecho Penal por la Universidad de Talca, candidato a doctor en Derecho por la Universidad de Chile. Dirección postal: Huerfanos 1219, Entrepiso, Santiago, Chile. Correo electrónico: manuel.rodriguez.vega@gmail.com 


\section{INTRODUCCIÓN}

En este trabajo se busca probar que en el procedimiento abreviado, como parte del consenso alcanzado entre acusador y acusado -y su defensa-, debe admitirse a los hechos accesorios de la acusación, porque permite por vía procesal ajustar la pena al injusto y a la culpabilidad concreta del ilícito cometido y a las consideraciones de prevención especial que el caso exige; lo cual es compatible con la exclusividad de la jurisdicción y los principios de igualdad y legalidad procesales.

Se expondrá, en primer término, el estado, en el ámbito comparado, de la discusión sobre los procedimientos penales donde confluyan los principios acusatorio, de oportunidad y del consenso o conformidad, y en que el ejercicio de la acción penal sea comandado por un organismo autónomo como el Ministerio Público, para llegar a aquellos sistemas en que, en ejercicio del principio de oportunidad, el Ministerio Público negocia con el imputado y su defensa los términos de la acusación, y da cuenta de las principales críticas a lo anterior, esto es, infracción del principio de obligatoriedad en el ejercicio de la acción penal o legalidad, de igualdad de trato y de exclusividad de la jurisdicción.

Visto lo anterior, examinaremos la legislación procesal penal nacional, observaremos cómo recoge los principios y organismos ya mencionados y cómo puede interpretarse el artículo 407 del Código Procesal Penal (= CPP.). Respecto de dicho precepto, que permite al fiscal modificar su acusación para posibilitar el procedimiento abreviado, plantearemos una interpretación acorde a los principios orientadores de la reforma procesal penal, y contradictoria con la sostenida hasta hoy por un sector importante de la doctrina que refleja las aprensiones desarrolladas por la dogmática foránea.

De ese modo, nuestra tesis intenta aportar una base dogmática ausente en la minoritaria doctrina nacional, que se ha manifestado favorable al consenso recaído sobre los hechos de la acusación en el procedimiento abreviado, la cual se ha limitado hasta hoy a remitirse al texto del artículo $407 \mathrm{CPP}$., o a invocar razones de eficiencia para el sistema, pero sin intentar construir un fundamento teórico sólido que los respalde.

\section{DESCRIPCIÓN DEL PROBLEMA Y PLANTEAMIENTO DE NUESTRA PROPOSICIÓN}

\section{Consenso sobre el mérito fáctico de la acusación en el Derecho comparado.} Estado de la cuestión.

Tras los dos grandes conflictos mundiales, en el ámbito europeo se llega a una situación insostenible para los tribunales de justicia, que resultaron 
incapaces de hacer frente al incremento generalizado y continuo de la criminalidad, así como a la creación de nuevos tipos penales, todo ello con una insuficiente dotación de medios personales y materiales ${ }^{1}$.

Frente a este panorama, las corrientes reformistas del entorno cultural europeo coincidieron en introducir diversas medidas para abordarlo, las que en el ámbito procesal penal, pueden encuadrarse en las siguientes ${ }^{2}$ : Se tiende a la consagración del sistema acusatorio, acentuando la publicidad y la oralidad de todo el proceso, con sustitución de la fase judicial instructora por una fase pre-procesal de investigación, cuya dirección se atribuye al Ministerio fiscal.

Igualmente se potencia el principio de oportunidad, el que en su sentido más estricto, exime al Ministerio Público del deber de ejercer la acción penal frente a todo hecho punible, ya sea absteniéndose de iniciar el proceso o abandonándolo una vez incoado ${ }^{3}$. Y junto a dichas soluciones se coincide en los países de tradición continental en adoptar, como mecanismo de aceleración del proceso, determinadas fórmulas de justicia negociada, entre las cuales prosperan no sólo aquellas que implican prescindir del proceso, al no ejercerse o abandonarse la acción penal (como las denominadas soluciones o salidas alternativas al proceso jurisdiccional), sino que también empieza a darse cabida en las legislaciones y en la jurisprudencia de estos países, a diversos tipos de procedimientos penales, donde, a grosso modo, se entrega al Ministerio Público facultades para hacer ciertas concesiones en el ejercicio de su acción a favor del acusado, de manera de recabar su consentimiento para someter el juzgamiento del ilícito y su responsabilidad, a un procedimiento que omita o acelere algunas etapas del proceso $\mathrm{o}^{4}$.

En el entorno latinoamericano, las reformas procesales penales se diseminaron rápidamente desde la última década del siglo $\mathrm{XX}$, donde catorce países y un número sustancial de provincias y estados latinoamericanos han introducido nuevos códigos procesales penales. Si bien estas reformas no han sido exactamente iguales en todas las jurisdicciones, los reformadores

\footnotetext{
${ }^{1}$ Armenta Deu, Teresa, Criminalidad de bagatela y principio de oportunidad: Alemania y España (Barcelona, PPU, 1991), pp. 220 ss.

${ }^{2}$ Se sigue en esta parte a Conde-Pumido Ferreiro, Cándido, El principio de legalidad y el uso de la oportunidad reglada en el proceso penal, en Revista Poder Judicial, extra 6 (1989), pp. 17-56,

${ }^{3}$ Desde ya conviene advertir, que se utilizarán las expresiones "principio de legalidad" y "principio de oportunidad”, pese a coincidir con Díez-Picazo, Luis María, El poder de acusar. Ministerio Fiscal y constitucionalismo (Barcelona, Ariel, 2000), p. 15, en su ambigüedad, y que, de mayor precisión sería valernos de las expresiones "obligatoriedad" y "discrecionalidad". Utilizaremos las primeras en atención al arraigo que en nuestra doctrina y jurisprudencia al menos, aquéllas han alcanzado.
}

${ }^{4}$ Cfr. Armenta Deu, Criminalidad de bagatela, cit. (n. 1), pp. 222 ss. 
las han descrito en términos similares, como una movida desde un sistema inquisitivo a uno acusatorio o adversarial; y como tales, las reformas tienen muchas características en común, incluyendo en lo que nos interesa, el permitir mecanismos de negociación y resolución alternativa de conflictos 5 . Refiriéndose al mérito y utilidad del instituto que puede catalogarse como paradigmático en el campo de los procedimientos basados en el consenso, el "plea bargaining", el Tribunal Supremo estadounidense ha expuesto que éste conduce a una rápida y definitiva solución de la mayoría de los procesos penales; evita muchos de los efectos corrosivos debido a la forzosa ociosidad durante la prisión preventiva de aquellos a quienes les ha sido denegada la libertad en espera del juicio; protege a la sociedad de aquellos acusados inclinados a persistir en su conducta criminal incluso durante su libertad provisional; y, abreviando los plazos que discurren entre la acusación y la sentencia, incrementa las perspectivas de rehabilitación del culpable una vez que, pronunciada la condena, éste venga sometido al tratamiento penitenciario ${ }^{6}$.

Por otro lado, y alejándose de enfoques eficientistas, diversos autores han cuestionado insistentemente este tipo de procedimientos consensuales, por conllevar la oferta de reducción de pena a cambio de la aceptación, no discusión, o confesión de los hechos de cargo y la renuncia al juicio oral, una especie de coerción psicológica que excluye la voluntariedad del acusado, pues, ante la posibilidad de terminar prontamente el proceso, y con ello las cargas que éste ha podido acarrearle, y además con una pena sustancialmente menor a la que obtendría en un juicio ordinario, el acusado se vería naturalmente compelido a dimitir a ejercer su derecho a un juicio oral ${ }^{7}$. Esta crítica, como ahora verificamos, se exaspera frente a procedimientos que admiten como objeto de la negociación entre el Ministerio Público y el acusado y su defensor, ya no sólo el rito a que se someterá el juzgamiento de los hechos, o la pena a que se expondrá el acusado, sino que incluyen también al mérito fáctico del proceso, permitiendo para ello al Ministerio Público disponer de éste con mayor o menor discreción.

${ }^{5}$ Langer, Máximo, Revolución en el proceso penal latinoamericano: Difusión de ideas legales desde la periferia [en línea] Centro de Estudios de Justicia de las Américas. <http://www.incipp.org.pe/modulos/documentos/descargar.php?id=273> [consulta: 22 de julio de 2010].

6 "Santobello v. New York", 404 U.S. 257, 260 (1971). En términos similares se había ya pronunciado la American Bar Association, en sus Standards for Criminal Justice, 1970, Commentary to Standard, 14.3.1, fn.12.

${ }^{7}$ Por todos, Langbein, John H., Tortura y "Plea Barganinig”, en Maier, Julio Bovino, Alberto (compiladores), El procedimiento abreviado (Buenos Aires, Editores del Puerto, 2001), p. 126. 
En efecto, en España, tras la reforma operada por la L.O. $N^{\circ} 7 / 1988$ al procedimiento abreviado y a la institución de la conformidad, autores como De la Oliva Santos han reclamado la inexistencia en el ordenamiento ibérico "de disposición alguna en la que se establezcan límites de cualquier tipo dentro de los cuales se autorice, en la acusación, la incidencia de criterios de oportunidad"8. Esto, a diferencia de otros como De Diego Díez, para quien, al igual que Italia y Portugal, las últimas reformas al proceso penal español lo han aproximado a un sistema de partes, a través de la utilización de mecanismos de consenso y de disposición sobre el objeto del proceso en la institución de la "conformidad del acusado".

En Italia, el sistema de partes norteamericano se deja sentir tanto en el procedimiento ordinario, como en cada uno de los procedimientos especiales previstos en su Código de Procedimiento Penal de 1988, entre los que destaca el juicio abreviado y el pacto, ambos fundamentados sobre el acuerdo del fiscal y el imputado ${ }^{10}$. El ámbito de la negociación sin embargo, está limitado constitucionalmente por el artículo 112 CPol.It., al prescribir éste que "el Ministerio Público tiene la obligación de ejercitar la acción penal”, lo que conlleva que la actuación del fiscal siga sometida al principio de legalidad u obligatoriedad de la acción penal ${ }^{11}$.

Alemania no prevé expresamente en su Ordenanza Procesal Penal (StPO.) la posibilidad de arribar a una solución jurisdiccional consensuada, sin embargo, se han desarrollado una serie de acuerdos o convenios informales entre fiscal, abogado y Juez, que tienen por objeto la solución anticipada del proceso. El Tribunal Constitucional alemán ha considerado que dichos acuerdos no son contrarios a la Constitución, pero precisando que debe quedar siempre a salvo el principio de investigación de la verdad real, así como las garantías procesales fundamentales del imputado ${ }^{12}$.

${ }^{8}$ De La Oliva Santos, Andrés, "Prólogo" a El"principio de consenso". La conformidad en el proceso penal español (Barcelona, Cedecs, 1998), p. 10.

${ }^{9}$ De Diego Díez, Luis Alfredo, La conformidad del acusado (Valencia, Tirant lo Blanch, 1997), p. 16. En el mismo sentido, el criterio de la Fiscalía General del Estado español, la cual sostiene en su Circular $\mathrm{N}^{\circ} 1 / 1989$, que la ley recoge hoy "el principio de consenso", esto es, el reconocimiento de un cierto margen de discrecionalidad en la actuación del Fiscal, a quien se permite plantear la acusación sin sujeción a criterios de pura y estricta legalidad.

${ }^{10}$ Spataro, Armando, "Italia" en Maciá Gómez, Ramón (director), Sistemas de proceso penal en Europa (Barcelona, Cedecs, 1988), pp. 262-263.

${ }^{11}$ Han existido diversos pronunciamientos de la Corte Constitucional italiana en esa dirección, que contrariando la intención original del CPP. italiano de 1988, en definitiva han mantenido las facultades del Ministerio Fiscal dentro de estrictos márgenes de legalidad, así, la sentencia rol № 313/1990, de 26 de junio de 1990.

${ }^{12}$ Aguilera, El principio del consenso. La conformidad en el proceso penal español 
El sistema de justicia estadounidense, por su parte, tanto en el ámbito federal, estatal, y local, consagra en términos muy amplios el principio de oportunidad, dejando la decisión de iniciar y mantener la persecución penal en manos exclusivas del fiscal. Este sistema contempla la institución que ha servido de modelo a los cambios procedimentales que revisamos, esto es, el "plea bargaining"13 el que si bien, centro de múltiples y siempre vigentes críticas a la discrecionalidad con que la Fiscalía ejerce la acción penal ${ }^{14}$, no es objeto ya de debate sobre su constitucionalidad, la que ha sido afirmada en diversas oportunidades por la Corte Suprema estadounidense, ${ }^{15}$ persiguiéndose hoy más bien mecanismos que, sin usurpar dicha discrecionalidad, hagan responsables a los fiscales de los abusos que en su ejercicio cometan ${ }^{16}$.

(Barcelona, Cedecs, 1998), p. 47; Shünemann, Bernd, Crisis del procedimiento penal (Marcha triunfal del procedimiento penal americano en el mundo), en Revista de Derecho Penal, 11, p. 14, Montevideo, acusa que la aplicación del sistema de consenso sería abiertamente antijurídica, al no encontrarse contemplada de modo alguno en el derecho legislado, y poniendo el acuerdo en peligro el ejercicio pleno de las garantías procesales que le caben al imputado. Denunciando los peligros que acarrea la "negociación del resultado del procedimiento entre los juristas profesionales” se ha pronunciado Hassemer, Winfried, Lineamientos de un proceso penal en el estado de Derecho, en El mismo, Crítica al Derecho penal de hoy (2 ${ }^{\text {a }}$ edición, $1^{\text {a }}$ reimpresión, Buenos Aires, Ad Hoc), pp. 98-99.

${ }^{13}$ De las dos modalidades del "plea bargaining", esto es, "sentence bargaining" y "charge bargaining" (contempladas en la "rule" 11a (e) (1) de las Federal Rules of Criminal Procedure) nos interesa sólo esta última, pues implica que el acusado se declare responsable y, a cambio, el fiscal renuncia a ejercer la acción penal por otros hechos que revisten caracteres de delito ("dismissal of charges"), retira alguno de los cargos mantenidos originariamente o califica los hechos de forma menos grave.

${ }^{14}$ Aguilera, El principio del consenso, cit. (n. 12), p. 29, sintetiza, como principales críticas al instituto del "plea bargaining", el afectar derechos y garantías constitucionales, como el derecho a un juicio público a través de jurado, el derecho a no declarar contra uno mismo; el ser el ahorro de tiempo y trabajo relativo, si el acuerdo se produce momentos antes del juicio oral; el desnaturalizar el papel de los intervinientes, cada uno de ellos impulsando el acuerdo sólo por la perspectiva de ahorrar tiempo; el aumentar la posibilidad de reconocerse culpable sólo para evitarse las molestias que implica la sujeción al proceso; y, afectar negativamente la dinámica de la negociación en la individualización de la pena. Más radical, LANGBein, Tortura y "plea bargaining”, cit. (n. 7), pp. 3 ss. , quien sostiene que el plea bargaining norteamericano ha terminado por abolir sustancialmente el sistema de juicios por jurados, marginándolo a un lugar en el cual, si bien persiste como un símbolo poderoso de legitimidad, carece de toda relevancia práctica. Agrega además que la generalización casi absoluta de este instituto, se debe a su estructura esencialmente coactiva, comparable con el mecanismo de la tortura propio del sistema inquisitivo imperante en la Baja Edad Media.

${ }^{15}$ V. gr. "Brady v. United States", 397 U.S. 742 (1970).

${ }^{16}$ Un reciente estudio sobre la necesidad de eliminar la arbitrariedad y responsabilizar a los Fiscales de las faltas cometidas en el ejercicio de su discrecionalidad en el sis- 
Efectuado este vistazo sobre el estado de la discusión en el Derecho comparado sobre el asunto que nos ocupa, veamos ahora con qué nos encontramos en el ámbito chileno.

\section{Consenso sobre el mérito fáctico de la acusación en el Derecho chileno.} Estado de la cuestión.

El nuevo proceso penal chileno, en operación desde diciembre del año 2000 , acogió ampliamente las vías ya vistas para solucionar las dificultades que también aquejaban el sistema de justicia nacional, no sólo de gestión y recursos, sino también de respeto al derecho al debido proceso y todo lo que éste implica. De ese modo consagró un sistema acusatorio, que dejó la investigación y el ejercicio de la acción penal preferentemente en manos de una institución constitucionalmente autónoma, como es el Ministerio Público (artículo $83 \mathrm{CPol}$.), la cual puede ejercer el principio de oportunidad dentro de ciertos límites (artículos 170 y 237 CPP.). Entre otros procedimientos alternativos al juicio oral, existe un procedimiento abreviado (artículo 406 ss. CPP.), que incluye ciertos márgenes de negociación con el acusado.

Dicho procedimiento abreviado consiste, en apretada síntesis, en el juzgamiento del acusado en base a los antecedentes investigativos recopilados por el Ministerio Público durante la fase de investigación, los cuales, el acusado declara aceptar ante el Juez de Garantía, al igual que los hechos de la acusación, renunciando por tanto al juicio oral, y, exponiéndose en caso de condena a una pena que no puede superar la solicitada por el fiscal o el acusador particular, si ésta fuera mayor. Este procedimiento nada más puede ser incoado a requerimiento del fiscal, y sólo cuando éste persiga en su acusación una pena privativa de libertad no superior a cinco años de presidio o reclusión menores en su grado máximo, o bien cualesquiera otras penas de distinta naturaleza, cualquiera fuere su entidad o monto, ya fueren ellas únicas, conjuntas o alternativas.

Si bien, el procedimiento abreviado, en cuanto institución procesal basada en el consenso, es aún objeto de críticas en la doctrina nacional ${ }^{17}$, principalmente por la coacción implícita en la exposición a una pena sustancialmente superior en caso de ejercer el derecho a juicio oral, hoy este procedimiento se ha legitimado y asentado con firmeza como parte esencial del sistema procesal penal, y la controversia se ha desplazado desde la esencia de la institución hacia la definición de sus contornos, es decir, hacia la precisión del objeto del consenso o pacto.

tema de justicia criminal estadounidense, en Davis, Angela J., Arbitrary Justice (New York, Oxford University Press, 2009).

${ }^{17}$ Cfr. Horvitz, María Inés - López, Julián, Derecho procesal penal chileno (Santiago, Editorial Jurídica de Chile, 2005), II, pp. 510 ss. 
El precepto cuya interpretación define dichos contornos o fronteras, es el artículo 407 CPP. Éste prescribe que: "si se hubiere deducido acusación, el fiscaly el acusador particular ${ }^{18}$ podrán modificarla según las reglas generales, así como la pena requerida, con el fin de permitir la tramitación del caso conforme a las reglas de este Titulo. Para estos efectos, la aceptación de los hechos a que se refiere el inciso $2^{\circ}$ del artículo 406 podrá ser considerada por el fiscal como suficiente para estimar que concurre la circunstancia atenuante del articulo 11, No 9 CP., sin perjuicio de las demás reglas que fueren aplicables para la determinación de la pena" ${ }^{19}$.

La inclusión por el Ministerio Público en su acusación de la atenuante del artículo 11 No 9 del Código Penal (en adelante, CP.), en conformidad con lo dispuesto en el artículo 407 CPP. ya visto, resulta muchas veces una mezquina recompensa para el acusado que renuncia al juicio oral -si se tiene a la vista la rebaja de un tercio de la pena que permiten el procedimiento abreviado y el pacto italiano, por ejemplo-, pues dicha modificatoria requerirá para posibilitar una rebaja sustantiva de la pena -de al menos un grado-, la concurrencia de otras mitigantes (artículo 67 inciso $4^{\circ}$ y 68 inciso $3^{\circ} \mathrm{CP}$.), o su consideración como muy calificada (artículo 68 bis CP.) ${ }^{20}$.

Frente a estas cortapisas para retribuir adecuadamente la renuncia al juicio oral que efectúa el acusado, el Ministerio Público ha optado por modificar el hecho fundante de su acusación, al socaire del texto del artículo 407, de tal manera que los hechos imputados se encuadren ahora en una figura de

${ }^{18}$ Aun cuando dentro del procedimiento abreviado, el querellante puede, al igual y con el mismo objeto que el Ministerio Público, llegar a un consenso con el acusado, y en base a este consenso, modificar su acusación particular, esta actuación del querellante, por la naturaleza de éste, no contraviene el principio de obligatoriedad en el ejercicio de la acción penal, al cual por cierto, no está sometido, motivo por el que la actuación en este ámbito del querellante no es objeto de nuestro estudio, salvo introductoriamente en lo que dice relación a su derecho a la tutela judicial efectiva o a la jurisdicción.

${ }^{19}$ Esta modificación está planteada en la ley para producirse sólo una vez que el Ministerio Público ya ha formulado su acusación por escrito, pues de no haberse aún presentado ésta, la acusación se formulará verbalmente en una audiencia especialmente fijada para ello, y en ese evento, contendrá directamente las modificaciones de cargos, pero en relación ahora no con una acusación previa, sino con los hechos que fueron objeto de la formalización de la investigación.

${ }^{20}$ Apremia compensar objetivamente al acusado más allá del reconocimiento de dicha minorante si se tiene en vista que parte de la jurisprudencia considera que el someterse al procedimiento abreviado, y la consiguiente renuncia al juicio oral, no la configura de por sí. V. gr. sentencias de la Corte de Apelaciones de Santiago, rol N ${ }^{\circ}$ 223-2005, de 30 de septiembre de 2005; y rol No 26-2006 de 20 de enero de 2006; sentencia de la Corte de Apelaciones de Copiapó rol N ${ }^{\circ} 292-2005$, de 12 de enero de 2006; y sentencia de la Corte de Apelaciones de Valparaíso, rol N ${ }^{\circ} 658-2005$, de 13 de julio de 2005. 
penalidad menor o no constituyan ahora alguna circunstancia calificante o agravante, todo ello, primero con el objetivo de situarse dentro del marco penal que permita proceder conforme al procedimiento abreviado -cinco años de presidio o reclusión-,y segundo, para obtener la anuencia del acusado a someterse al mismo, renunciando al juicio oral mediante la aceptación de hechos y antecedentes investigativos que supone.

La modificación de los hechos de la acusación podría, en principio, avalarse, pues si el legislador permite al Ministerio Público, no obstante encontrarse ya agotada y cerrada la investigación y presentada una acusación respetuosa del principio de objetividad, modificar los hechos del libelo acusatorio, ello parece que no puede ser sino el resultado de la posterior negociación con el acusado $^{21}$, a quien, a cambio de su sometimiento al procedimiento abreviado, se busca compensar mediante el ajuste del presupuesto fáctico a una figura o calificación que conlleve una morigeración punitiva.

Un sector de la doctrina local se ha opuesto a la posibilidad de esta modificación a la acusación, amén de las críticas de coacción al justiciable y haciendo eco de lo visto en el ámbito comparado, por estimar que vulnera los principios de legalidad, igualdad de trato y exclusividad de la jurisdicción ${ }^{22}$. Propugnan entonces un activo control judicial de la correlación de los hechos de la acusación con los antecedentes investigativos reunidos por el Ministerio Público, lo cual, sostienen ellos, permitiría el artículo 410 CPP. al instruir que el juez aceptará la solicitud de procedimiento abreviado "cuando los antecedentes de la investigación fueren suficientes".

Acoger la posibilidad de modificar la acusación, por el contrario, supondrá aproximarnos más de lo que el legislador tuvo en mente y de lo que la mayoría de nuestra doctrina anhelaría, a la institución del "plea bargaining"23,

${ }^{21}$ En el mismo sentido respecto del sistema español, De Diego Díez, La conformidad del acusado, cit. (n. 9), pp. 150-151, con cita a diversos otros autores españoles en nota 223.

${ }^{22}$ Cfr. Pecchi Croce, Carlos, El procedimiento abreviado en el nuevo Código Procesal Penal, en Revista de Actualidad Jurídica, 11 (enero 2005), p. 132; y Del Río, Carlos, Proceso penal, consenso de las partes y enjuiciamiento jurisdiccional. Santiago, (Santiago, Librotecnia, 2009), pp. 31-32.

${ }^{23} \mathrm{~A}$ favor de un manejo laxo de los hechos, con vista a adecuar el relato fáctico a las necesidades del ámbito objetivo del procedimiento, véase: Riego Ramírez, Cristián, El procedimiento abreviado, en AA. VV., Nuevo proceso penal (Santiago, ConoSur, 2000), pp. 205-226. Resulta llamativo además que ya en el año 1998, al analizar el proyecto de ley del que habría de ser el nuevo Código Procesal Penal, Amвos, Kai, El proceso penal alemán y la reforma en América Latina (Santa Fe de Bogotá, Gustavo Ibáñez, 1998), pp. 95-96, concluya que el proyecto chileno adopta la estructuralmente el modelo del procedimiento angloamericano, postergando conscientemente el principio de la verdad material a favor de elementos consensuales. 
no obstante mantener una sana distancia con ella, pues en nuestro procedimiento abreviado el acuerdo entre el fiscal y el acusado no es vinculante para el Juez, es decir, no excluye un pronunciamiento absolutorio, precisamente porque la acusación debe tener respaldo en los antecedentes investigativos y la sentencia debe ser fundada ${ }^{24}$.

\section{Hacia una interpretación verdaderamente garantista del articulo 407 CPP.}

Poco a poco hemos ido acercándonos al problema que pretendemos abordar, esto es, si dentro del consenso alcanzado entre acusador y acusado en el procedimiento abreviado cabe considerar los hechos de la acusación, y cómo ello, en su caso, no es incompatible con la exclusividad de la jurisdicción y los principios de igualdad y legalidad. Cómo se decante esta discusión tendrá injerencia más allá del propio procedimiento abreviado, pues el principio de igualdad compelería a extender la posibilidad de llegar a un consenso sobre el mérito del proceso también al encausado bajo las normas del procedimiento simplificado de resolución inmediata.

Y frente a esa disyuntiva, nuestra respuesta es afirmativa, y como intentaremos demostraremos aquí, además fundada. Sin embargo será insuficiente si sólo nos circunscribimos a demostrar que es una respuesta, al igual que la posición doctrinal y jurisprudencial que refutamos, compatible con nuestro ordenamiento. Debemos entonces adelantar porqué también es una mejor respuesta. Y lo es por dar salida al pétreo y rígido sistema de determinación judicial de la pena consagrado en nuestro Código Penal, permitiendo de ese modo al Ministerio Público morigerar el rigor inicial de la acusación, cuando ésta, de conservar un estricto apego al principio de legalidad, conlleve una pena excesivamente cuantiosa en proporción al injusto y culpabilidad del caso particular, o a las necesidades preventivas del autor ${ }^{25}$, todo ello, "siempre que la defensa del ordenamiento jurídico (es decir, la reserva mínima que impone la prevención general) así lo permita"26.

${ }^{24}$ Por ello no cabe estimar que la sentencia judicial en el procedimiento abreviado nacional sea un mero acto de "homologación de decisiones ajenas", como se ha sostenido de la vinculación del juez al hecho materia de "conformidad" por el acusado en el proceso español, al no tener en éste el tribunal facultades para revisar la prueba de cargo.

${ }^{25}$ El Código Procesal Penal no contempla una norma como el $₫ 46$ del StGB., el cual señala expresamente la culpa como fundamento de la medición de la pena, y la consideración de los efectos derivados de la pena para la vida futura del autor en la sociedad, amén de otros factores sobre la culpabilidad e injusto del hecho, como otras consideraciones de prevención especial.

${ }^{26}$ Roxin, Claus, Culpabilidad y prevención en el Derecho penal (traducción de Francisco Muñoz, Madrid, Reus, 1981), p. 110. 
Tal modificación de los presupuestos fácticos de la acusación no debe ser absoluta, sino restringirse a prescindir de sus elementos o hechos no esenciales, los cuales, en nuestro planteamiento, consistirán en los siguientes ${ }^{27}$ :

1) aquellos hechos que autónomamente se subsumen en una figura delictiva, pero de bagatela, y que no constituyen lo central de la imputación, pudiendo respecto de ellos el Ministerio Público ejercer la facultad de abandonar la investigación conforme al artículo 170 CPP., razón por lo que este primer supuesto no debiera suscitar mayor oposición doctrinal, cuando dicho abandono responde a una negociación previa del Ministerio Público y acusado, v.gr. prescindir en la acusación de la imputación del delito de porte de arma blanca y sólo perseguir el delito de microtráfico, respecto del acusado al que se sorprende vendiendo pequeñas cantidades de droga en la vía pública, portando además un arma blanca sin justificación.

2) aquellos hechos que sólo configuran circunstancias agravantes de responsabilidad penal, y que por tanto, desprenderse de ellos no implica modificar el hecho típico y su calificación jurídica, $v$.gr. prescindir de la agravante contenida en el artículo $12 \mathrm{~N}^{\circ} 16 \mathrm{CP}$., esto es, "haber sido condenado el culpable anteriormente por delito de la misma especie"; $y$,

3) aquellos supuestos de hecho, cuya omisión conlleva alterar el hecho típico, pero sólo en la medida que la calificación jurídica se atenúa a otra de menor penalidad, manteniendo lo central de la conducta y del bien jurídico afectado, $v \cdot g r$. desentenderse del desempeño sorpresivo en la sustracción, para que ésta no sea calificada como Robo por sorpresa, sino sólo como Hurto, cuando el valor de la especie sustraída acarree una sanción menor.

Los autores locales, en lo que atinge a las dos últimas situaciones men$\operatorname{cionadas}^{28}$, no han intentado siquiera explicar el porqué abandonar en la acusación la persecución de un delito autónomo en conformidad al artículo 170 CPP. es una situación tolerable -y muchas veces considerada loable-,y no lo es en cambio abandonar la persecución de una circunstancia agravante o de un supuesto fáctico que no altera la esencia de la conducta atribuida. En todas estas situaciones se actuaría discrecionalmente por el Ministerio Público, en las tres la pena total a imponer se reduce sólo relativamente, en todas ellas la víctima tiene posibilidades de oponerse y frustrar el consenso

${ }^{27}$ Esta propuesta no pretende en este punto ser novedosa, pues se puede englobar en la modalidad del "plea bargaining", conocida como "charge bargaining", comentada ya en la nota 13 .

${ }^{28}$ Del Río, Proceso penal, cit. (n. 22), pp. 81 ss. las considera como parte de las "prácticas inadecuadas de la jurisprudencia", consistentes en "el abandono de hechos agravantes (existentes)" y "la incorrecta modificación de la calificación jurídica de la acusación a través de la degradación de ésta”. 
alcanzado entre Ministerio Público e imputado ${ }^{29}$, igualmente las dos últimas pueden justificarse, así como la primera, en los intereses de eficiencia en la administración de los recursos económicos del aparato de persecución y juzgamiento estatal, y principalmente, todas ellas pueden permitir ajustar la pena concreta a imponer al injusto y culpabilidad del caso particular, o a las necesidades preventivas del autor ${ }^{30}$.

Alterar la esencia del hecho atribuido, como transitar de un delito de robo en lugar no habitado al de receptación, excede nuestra propuesta y no puede ser dispensado, pues se aleja de una simple limitación de los hechos imputados con miras a ajustar la pena probable al injusto, culpabilidad o necesidades concretas de prevención, y se cae en una manipulación fáctica que se desentiende totalmente de la investigación previa, y que de aceptarse supondría la posibilidad de condenar a una persona por hechos que no ha cometido - a diferencia de nuestras tres propuestas anteriores, donde el acusado sí es sancionado por el hecho que perpetró, sólo dejándose de lado circunstancias que harían esa sanción más grave- ${ }^{31}$. Dilucidado el acicate que impulsa nuestro planteamiento, y en forma previa a entregar una mirada a su

${ }^{29} \mathrm{El}$ artículo $170 \mathrm{CPP}$. permite a la víctima reclamar dentro del $10^{\circ}$ día, reanudando el proceso; y respecto de las otras dos situaciones véase lo expuesto infra sobre la tutela judicial efectiva de la víctima en el procedimiento abreviado.

${ }^{30}$ Pareciera que aquí las razones sustantivas para oponerse a lo propuesto quedan en un segundo plano, y se imponen meras razones de texto, como que si el hecho respecto del cual se abandona la persecución no es un delito autónomo, no será posible determinar si al ejercer dicha facultad del artículo 170 CPP., el Ministerio Público excede o no los márgenes legales. Sin embargo, podemos conjeturar como respuesta que el legislador expresamente autoriza al Ministerio Público para abandonar la persecución de "hechos" que no comprometieren gravemente el interés público, y no sólo de "hechos que constituyan delitos" -sólo respecto de los cuales estaría establecida las limitaciones de pena y autor prescritas en el citado artículo 170-, y por tanto, es posible considerar como parte de dichos hechos los señalados arriba en las propuestas 2) y 3 ).

${ }^{31}$ Amén de lo anterior, una alteración esencial de los hechos de la acusación por parte del Ministerio Público expone a éste a un pronunciamiento absolutorio, ya que si tales sucesos difieren sustancialmente de los de la formalización previa, podría ello obstar a que el juez condene por hechos diversos a los que fueron objeto de la comunicación inicial y de la investigación consecuente, por infringir el principio de congruencia como manifestación del derecho a defensa (artículo 259 inciso final en relación al artículo 341 inciso $1^{\circ} \mathrm{CPP}$.), y por otra parte, los nuevos hechos sustancialmente diversos generalmente no estarán respaldados por los antecedentes investigativos que el Juez tiene obligación de revisar y usar como fundamento de su sentencia condenatoria en el procedimiento abreviado, precisamente porque la investigación estaba dirigida a dilucidar un hecho esencialmente diverso - cuestiones ambas que no sucederían si sólo se tratara de cambios accidentales al hecho materia de la acusación-. 
núcleo teórico, conviene hacer tres prevenciones cuya consideración puede orientar mejor el discernimiento de lo que vendrá.

Primero, la construcción de nuestra propuesta implica una reinterpretación que profundice, y en ciertos casos exacerbe, los mismos institutos y principios liberales insertos en el CPP., como la pasividad del Tribunal en la fase de juzgamiento, la autonomía del Ministerio Público, y el principio de oportunidad, por adelantar algunos, de manera que no debe extrañar si una revisión de la historia legislativa del CPP., evidencia que nuestras metas no parecen haber sido las del legislador, o incluso ser contradictorias con las de éste, pues el codificador procesal del año 2000 buscó asentar las diferencias esenciales con el sistema inquisitivo que dejaba atrás después de varios siglos de imperio. Nosotros en cambio, buscamos extender y arraigar las raíces del principio acusatorio ya plantado, de manera que éste sea capaz de resistir la ventisca inquisitiva que de tanto en tanto lo remece.

Segundo, en algunos países, la doctrina ha reclamado que la modificación de la acusación en los términos que nos ocupan, ni siquiera está autorizada legalmente, como sucede por ejemplo en España, donde se ha dicho que la introducción del principio de oportunidad y de consenso en el proceso penal español ha sido "solapada y clandestina" 32 . Pues bien, el artículo 407 CPP. permitirá comenzar nuestra argumentación con cierta ventaja entonces, al visar este precepto expresamente la modificación de la acusación.

En efecto, el artículo 166 CPP., que consagra el principio de legalidad como rector del ejercicio de la acción penal por el Ministerio Público, dispone que éste sólo podrá suspender, interrumpir o hacer cesar la persecución penal, "en los casos previstos en la ley", siendo uno de ellos, según sostendremos aquí, el artículo 407 CPP., el cual constituye una manifestación en la acusación de su principio opuesto, esto es, la oportunidad, mediante una persecución penal que si bien no se abandona, se autolimita en intensidad ${ }^{33}$.

Allanará también nuestro camino, el no estar recogida la obligatoriedad en el ejercicio de la acción penal en nuestro texto constitucional, a diferencia del artículo 112 CPol.It. por ejemplo, no siendo por ende imperioso inter-

${ }^{32}$ Aguilera, El “principio de consenso", cit. (n. 12), p. 20.

${ }^{33}$ En el mismo sentido, tras la reforma a la Ley de Enjuiciamiento Criminal española con la L.O. $\mathrm{N}^{\circ} 7 / 1988$, la mayor parte de los autores hispanos coinciden en configurar el instituto de la conformidad como manifestación del principio de oportunidad en el proceso penal español. Así CaBAÑas García, J. C., El proceso penal español ante una perspectiva de justicia penal negociad, en. Revista de Derecho Procesal, 2 (1991), 262 ss.; Armenta Deu, Criminalidad de bagatela, cit. (n. 1), pp. 213 ss.; Barona Vilar, Silvia, La conformidad en el proceso penal (Valencia, Tirant lo Blanch, 1994) pp. 222 ss.; y, Gimeno Sendra, Vicente, La nueva regulación de la conformidad (Ley Orgánica 7/1988), en Revista La Ley, 3 (1990), pp. 977-978,. 
pretar nuestras normas adjetivas o todo el estatuto del Ministerio Público exclusivamente a la luz de dicho principio ${ }^{34}$.

Y tercero, lo aquí propuesto requiere asimilar que la tarea será no sólo dar mejores razones que las esgrimidas por las tesis contrarias o divergentes a la nuestra, sino que también se deberá lidiar con una cultura jurídica recelosa de la capacidad racional de los acusados para, bajo la orientación y tutela de un defensor del Estado y un juez garante, decidir libre y razonadamente sobre la conveniencia de la rebaja de cargos ofertada por el Ministerio Público, como escéptica y aprensiva sobre la aptitud de los representantes del Ministerio Público para un ejercicio no arbitrario de su facultad de negociación. Dicho recelo, escepticismo y aprensión, tiene como contracara un injustificado exceso de optimismo sobre lo objetivo y preclaro que puede llegar a ser un Juez en el desempeño de sus funciones.

\section{DisCUSIÓN DE TEORÍAS Y CONCEPTOS QUE SOSTIENEN LA PROPUESTA}

Revisemos por fin los institutos o conceptos que dan cimiento teórico a este planteamiento, y que a su vez nos permiten hacernos cargo de sus principales objeciones, concernientes al principio acusatorio, al Ministerio público como organismo autónomo y co-director de política criminal y al principio de oportunidad y su relación con la prevención especial.

\section{El principio acusatorio.}

Nuestro codificador procesal penal, a diferencia de la opción general de los otros países que participan del último proceso reformador Latinoamericano por el modelo instructorio, prefirió un procedimiento contradictorio, esto último debido a la influencia del Código Procesal Penal Modelo de 1988, el cual está decididamente orientado hacia los ordenamientos procesales continentales-europeos ${ }^{35}$. Dicho avance de nuestra legislación adjetiva, nos permite ahora centrar la atención más bien en extirpar los resabios del inquisitivismo que se mantienen enquistados en nuestra legislación y prácticas judiciales, y a perfeccionar las instituciones que constituyan una

${ }^{34}$ En sentido contrario, la prevención a la sentencia del Tribunal Constitucional de 3 de febrero de 2000, rol N³04, suscrita por Mario Verdugo M. y Juan Colombo C., quienes abogan por un deber del Estado de sancionar al hechor, desprendido ello del artículo 1 CPol.: citada por Colombo Cambell, Juan, Aspectos Constitucionales de la Reforma Procesal Penal, en Revista de Derecho Procesal, 20 (2005), pp. 9-38,

${ }^{35}$ Амвоs, El proceso penal alemán, (n. 24), p. 38. 
manifestación del principio acusatorio, pues un proceso inspirado en éste es el que mejor satisface las exigencias de justicia de nuestra sociedad ${ }^{36}$.

Y dicho perfeccionamiento, hoy demanda releer el artículo 410 CPP. cuando éste requiere para acceder al procedimiento abreviado que "los antecedentes de la investigación fueren suficientes", íntimamente vinculado con el artículo 407 en estudio, pues en base a aquél nuestra doctrina y jurisprudencia ha estimado que el Juez de Garantía, en el examen de admisibilidad de la solicitud de procedimiento abreviado efectuada por el fiscal y el imputado, debe ya verificar primero la existencia de antecedentes investigativos que comprueben cada elemento de la acusación -discutiéndose la cantidad y entidad de estos antecedentes ${ }^{37}$-, y segundo, que no se hayan dejado de lado en la acusación circunstancias fácticas de que den cuenta los antecedentes investigativos, y que hubiesen llevado a encuadrar los hechos en una figura penal más gravosa ${ }^{38}$.

Una adecuada relectura debe profundizar la separación entre acusador y juzgador, dándole un sentido garantista a esa exigencia impuesta por el legislador en el citado artículo 410, de manera que, sobre el primer aspecto mencionado de la revisión de antecedentes, éste no se efectúe por el Tribunal con el objeto de advertir al Ministerio Público de las falencias de su acusación antes de que vuelva a ser formulada -emplazándonos en la situación más común donde el texto escrito de la acusación aún no ha sido presentado y

${ }^{36}$ Ruiz VAdillo, Enrique, El Derecho Penal en la encrucijada del año 2000, en EL MISmo, Estudios de Derecho procesal penal (Granada, Comares, 1995), p. 13.

${ }^{37}$ La doctrina está más o menos conteste en exigir sólo una suficiencia razonable, es decir, que exista "al menos un antecedente, aunque sea sucinto, para comprobar cada elemento de la acusación”, Horvitz - López, Derecho procesal penal chileno, cit. (n. 17), II, p. 527. Véase también: Cerda SAN Martín, Rodrigo - Hermosilla IriarTE, Francisco, El procedimiento abreviado (Nuevo sistema procesal penal) (Santiago, Metropolitana, 2003), p. 46.

${ }^{38}$ Cfr. sentencia de la Corte de Apelaciones de Rancagua, rol No 37-2004, de 23 de junio de 2004: "Que la referencia del legislador, en el citado artículo 410, a los antecedentes de la investigación, como parámetro para decidir si se hace o no lugar a la solicitud... importa que ha de existir en ese momento algún análisis por parte del Juez respecto de los hechos del fondo y de los tipos en que el Ministerio Público los encuadre, y ello sólo puede tener sentido si se trata de determinar si esos hechos corresponden a esos tipos y si esos tipos hacen legalmente procedentes las penas reclamadas por la Fiscalia, vistas las circunstancias de iter criminis, participación o de modificación de la responsabilidad que el acusador indique. Analizado todo ello, el Juez de Garantía admite o no que se proceda mediante juicio abreviado. $Y$ en ese momento puede, con todo derecho, rechazar el procedimiento pedido si entiende que la pena propuesta es ilegal por no ajustarse al tipo, tal como ocurre si en un cuasidelito cometido con vehiculo motorizado se omite la pena de suspensión de licencia, que es obligatoria; $y$, en tal evento, dictará el auto de apertura del juicio oral y será ese el procedimiento por el que seguirá la causa" 
el marco penal correcto a juicio del Tribunal permite celebrar igualmente el juicio abreviado- sino muy por el contrario, para denunciar cuando la investigación no haya sido exhaustiva para agotar la pesquisa de versiones que excluyan o atenúen la responsabilidad del acusado, única alternativa que resguarda tanto la imparcialidad del Juez como la autonomía del Ministerio Público.

Contrariamente a lo que parte importante de nuestra doctrina ha creí$\mathrm{do}^{39}$, cuando la acusación no contiene suficientes antecedentes investigativos para acreditar el hecho punible o alguna circunstancia agravante, la solución respetuosa de los principios de separación de acusación y juzgamiento, de la carga formal de la prueba en la acusación, y de la presunción de inocencia del acusado, es aceptar la renuncia al juicio oral, admitir la procedencia del juicio abreviado, y a reglón seguido, absolver o condenar sin consideración a la agravante no justificada, respectivamente ${ }^{40}$.

Y en lo que dice relación al segundo enfoque de la revisión judicial de antecedentes, cualquier control jurisdiccional sobre la correlación de la acusación con los antecedentes investigativos efectuado para constatar que éstos dan cuenta de un hecho punible o de circunstancias que derivan en un marco penal mayor, pero anclado al final del proceso -como lo parece el artículo 410 CPP. en la tesis doctrinal que cuestionamos-, es inoperante si conlleva la superación de etapas donde ya se ha consumado la discrecionalidad del Ministerio Público y que a dicha altura no es posible revertir ${ }^{41}$,

${ }^{39}$ Cfr. Del Río, Proceso penal, cit. (n. 22), p.139; Horvitz - López, Derecho procesal penal chileno, cit. (n. 17), II, pp. 527 y 533; PECCHI, El procedimiento abreviado, cit. (n. 22), pp. 411 ss.; FALCONE, Diego, La absolución en el procedimiento abreviado, en Revista de Derecho de la Pontificia Universidad Católica de Valparaíso, 26 ( $1^{\mathrm{er}}$ semestre 2005), pp. 363 ss.; Salas Astrain, Jaime, Problemas del proceso penal (Santiago, Librotecnia, 2009), pp. 239 ss.

${ }^{40}$ Diversos fallos de tribunales superiores chilenos avalan esta conclusión, entre los que podemos mencionar, sentencia de la Corte de Apelaciones de Santiago, rol N ${ }^{\circ}$ 934-2006, de 7 de junio de 2006: "la circunstancia que el imputado, en conocimiento de los hechos materia de la acusación y de los antecedentes de la investigación que la fundan, haya aceptado expresamente y manifestado su conformidad con la aplicación del procedimiento abreviado, en los términos que dispone el artículo 406 del Código Procesal Penal, a juicio de estos sentenciadores, no obsta a que el juez en la sentencia definitiva absuelva al acusado, de acuerdo a lo previsto en el artículo 413 del señalado cuerpo legal", y sentencia de la Corte de Apelaciones de Valparaíso, rol No 715-2005, de 22 de julio de 2005: "la aceptación de los hechos por parte del imputado debe decir relación con los antecedentes de la investigación que fueren aportados por el Ministerio Público, situación que como se ha establecido en este fallo, no ocurrió respecto de la notificación de las medidas en cuestión y por lo demás, el fallo nunca se puede fundar exclusivamente sobre la base de la aceptación de los hechos, puesto que ello implicaría vulnerar el articulo 412."

${ }^{41}$ En efecto, es irreconciliable sostener la posibilidad de un control judicial sobre 
sin admitir que el Juez vuelva a tomar el protagonismo como controlador de “toda” la investigación, lo que precisamente se buscó evitar mediante la implementación de un sistema acusatorio ${ }^{42}$.

Ninguno de quienes rechazan la posibilidad de disponer de la acusación por parte del Ministerio Público, parece haber advertido que no pocas veces la formulación de una acusación que no contemple todos los hechos de que da cuenta la investigación, y que de hacerlo conllevaría una calificación jurídica más gravosa o la concurrencia de otras agravantes, puede no obedecer a un convenio previo del Ministerio Público con el imputado y su defensa, sino simplemente, como veremos luego, a la convicción jurídica del fiscal de que el artículo 407 CPP. le otorga una herramienta para ajustar la pena concreta a la culpabilidad y necesidades de prevención especial del caso, o muy por el contrario, dicha omisión puede responder a una falta de acuciosidad de parte del fiscal acusador en la revisión de los antecedentes de la investigación, a su temor o inseguridad para proponer ya sea, unos hechos que no sabe si será capaz de acreditar en el juicio, o una calificación jurídica que es desestimada por la doctrina mayoritaria - pero que sin saberlo, el Juez que dirigirá la audiencia comparte-, o simplemente a torpeza o ignorancia en la apreciación jurídica.

Quienes niegan todo margen de discreción en la formulación de la acusación, no debieran distinguir entre todos esos casos, porque más allá de la dificultad de efectuar tal distingo, todos ellos vulnerarían la exclusividad de la jurisdicción, el principio de legalidad e igualdad de trato. Y convenido o asumido lo anterior, qué duda puede caber que el principio inquisitivo aún pervive si frente a un acusador negligente, que omite hechos en su acusación que conducen a la rebaja del marco penal, el Juez le previene de ello, y no sólo eso, lo conmina a subsanar esa omisión en su acusación como condición para que se admita el juicio abreviado que él mismo fallará - para efectos de nuestro razonamiento, supongamos una acusación verbal y que la pena

el contenido de la acusación, sin tampoco reconocerlo sobre la formalización de la investigación que aquélla no puede exceder en base al principio de congruencia (artículo 341 CPP.), si ya en la comunicación de cargos el Ministerio Público hizo uso de sus facultades discrecionales para atribuir los hechos.

${ }^{42}$ Como reflexiona Roxin en relación con el sistema alemán -reflexión plenamente aplicable al chileno-, el Ministerio Público no es un agente ejecutor de la jurisdicción, sino su par, en igualdad de condiciones, en la administración de justicia, y en esta posición, es llamado a efectuar un juicio jurídico independiente. Es más, agrega el mismo autor, la separación de la actividad de perseguir y la de decidir tiene no sólo el fin psicológico-procesal de asegurar al juez una objetividad elevada, sino que protege también al imputado de la posible valoración parcial de una sola autoridad judicial. Roxin, Claus. Posición jurídica y tareas futuras del Ministerio Público, en MaIer, Julio B (compilador), El Ministerio Público en el proceso penal (Buenos Aires, Ad Hoc, 2000), p. 48. 
correcta a juicio del Tribunal sigue estando dentro del marco del procedimiento abreviado $-{ }^{43}$. Aquí, apreciar dos actividades estatales autónomas, la de acusar y juzgar, es sólo una ilusión, y en verdad, una mirada atenta nos mostrará que en estas circunstancias ambos -fiscal y Juez-interpretan en cierto modo el papel de acusador ${ }^{44}$.

Por eso hemos de insistir en que los controles sobre las situaciones que arriba hemos enunciado ilustrativamente, deben ser prioritariamente internos a la organización jerárquica propia del Ministerio Público, a fin de evitar un retorno solapado de la actividad inquisitiva del Tribunal ${ }^{45}$.

${ }^{43}$ Situaciones como las aludidas harán más atingente meditar la propuesta de NúÑEz Ávila, René, ¿Debe fallar el juez de garantía el procedimiento abreviado? en Revista Procesal Penal, 43 (LexisNexis, 2006), pp. 13-18, para que el juez de garantía no falle el procedimiento abreviado, sino remita su conocimiento al Tribunal de Juicio Oral en lo Penal.

${ }^{44}$ De Diego Díez, La conformidad del acusado, cit. (n. 9), p. 285, precisa que para que exista proceso y ejercicio de la potestad jurisdiccional, es preciso que la actividad de los tribunales se promueva desde fuera de ellos, mediante el ejercicio de la acción (" $u b i$ non est actio, non est iurisdictio"). La Corte Suprema ha dado señales en la línea correcta en causa rol $\mathrm{N}^{\circ}$ 4.180-2004, de 25 de enero de 2005, al fallar que el juez de garantía: " $n o$ puede [...] inmiscuirse en la pena que el fiscal entiende corresponde al delito, como tampoco en el procedimiento al cual se va a ceñir el juicio, porque ello necesariamente supone entrar a efectuar una valoración a priori e invadir un campo que le está vedado". $\mathrm{V}$

Véase también la sentencia de la Corte de Apelaciones de Valdivia, rol No $75-2009$, de 4 de marzo de 2009: "teniendo presente que el modelo de sistema que impera en el Código Procesal Penal consiste en entregar sólo al Ministerio Público la investigación, y por eso a ellos exclusivamente les corresponde valorar el mérito de la misma, y por ende, lo que decidan a su respecto no está sujeto a revisión por parte del Juez respectivo".

${ }^{45}$ No obstante ello, porque, como se ha encargado de precisar la Corte Suprema, el ejercicio discrecional de las diversas prerrogativas que se han otorgado al Ministerio Público, no importa permitir la arbitrariedad en su desempeño, pues "esta hipótesis se encuentra excluida por el conjunto de disposiciones contenidas en dicho cuerpo legal y en la Ley Orgánica Constitucional del Ministerio Público, que reglan sus potestades y que establecen el control jerárquico y jurisdiccional de su actuación" (sentencia rol № 1.467 2009, de 29 de diciembre de 2009, reafirmada en rol $N^{\circ} 1.445-2009$, de 29 de enero de 2010, y rol $\mathrm{N}^{\circ} 1.394-2009$, de 13 de julio de 2010), creemos que de hacer el fiscal un uso abusivo o extremo de sus facultades discrecionales en la enmienda de la acusación, el juez no debe permanecer impávido frente a lo que puede ser indiciario de un procedimiento viciado en alguna etapa de su desarrollo, de algún supuesto de corrupción del fiscal acusador, o simplemente de una actuación antojadiza carente de fundamento. En estos casos, parece razonable previamente a la sustanciación del procedimiento abreviado, indagar los motivos de esta excesiva alteración de la acusación, y en su caso, requerir de la autoridad superior del Ministerio Público un pronunciamiento que avale o explique la pretensión dubitada. Adviértase que incluso en el sistema estadounidense, que como es bien sabido a esta altura, concede amplio margen discrecional al acusador, se han rechazado acuerdos por estimar que la modificación de un delito de asalto grave 
Esta lectura del artículo 407, que por cierto limita el campo de acción del Tribunal, pues éste se pronunciará sólo sobre los hechos de la acusación ${ }^{46}$ tal y como sea formulada por el Ministerio Público producto de la convención con el acusado, no cercena o invade la exclusividad de la jurisdicción de los Tribunales, pues precisamente su rol imparcial -y por tanto, pasivo- en este sistema acusatorio, lo aleja insoslayablemente de pretender alcanzar la verdad material, la que es superada por una verdad formal o consensuada, obtenida del contraste de las hipótesis acusatorias y la refutación por parte de la defensa, o verdad "forense" como la llama Hassemer, por ser obtenida de acuerdo con las formalidades judiciales ${ }^{47}$. Los Tribunales ya no "averiguan" qué fue lo que realmente sucedió, ello es ahora función del Ministerio Público, y cuando éste cree haberlo averiguado, planteará una hipótesis fáctica

a conducta desordenada, constituye una "excesiva benevolencia para el acusado" ("City of Akron v. Ragsdale” 399 N.E. 2d. 119, Ohio Ct. App. 1978); y en otra oportunidad se estimó por una Corte de Circuito que el Juez de distrito sólo podía rechazar el acuerdo cuando se entendiese que es producto de un abuso en la discreción del fiscal ("United States v. Ammidown”, 497 F. 2d 615 (D.C. Cir. 1973). En Inglaterra y Gales la revisión judicial sobre el ejercicio de la discreción de los fiscales de la Corona está limitada a decisiones que sean completamente irracionales. Амвоs, Kai, Estatus, función y responsabilidad del fiscal desde el punto de vista del Derecho comparado, en El Mismo, Estudios del Derecho penal y procesal penal (Santiago, Editorial Jurídica de Chile, 2007), p. 313. En Alemania, por su parte, el Tribunal Supremo reconoce la posibilidad de efectuar una reclamación por incumplimiento del deber de persecución y averiguación. Véase: Revista del Tribunal Supremo (BGHZ.) citada por Armenta Deu, Criminalidad de bagatela, cit. (n. 1), p. 82.

${ }^{46}$ De Diego DíEz, Luis Alfredo, El control judicial sobre la conformidad del acusado, en Revista Poder Judicial, 23, pp. 35-36, sostiene respecto del instituto de la conformidad de la Ley de Enjuiciamiento Criminal española, que la determinación del objeto del proceso, esto es, la fijación del hecho criminal y la persona a la que se acusa del mismo, es algo que corresponde exclusivamente a las partes acusadoras, de tal forma que "cualquier intromisión del órgano jurisdiccional en esta función -ya sea a favor, ya en contra del acusado- habría de ser considerada como una intolerable dejación de la imparcialidad que le caracteriza, convirtiéndose irregularmente en acusador. Ello, obviamente, conculca el principio acusatorio [...]". MATUs AcUÑA, Jean-Pierre, La justicia penal consensuada en el nuevo Código de Procedimiento Penal, en Revista CREA, 1 (Universidad Católica de Temuco, 2000), p. 128, señala que parece improbable que el sólo acuerdo entre el Ministerio Público y el imputado obliguen al juez a apreciar los hechos y calificarlos conforme lo solicita el primero, a lo cual adherimos, sólo agregando que el hecho que va a ser objeto de apreciación y calificación judicial lo determina la acusación del Ministerio Público.

${ }^{47}$ Hassemer, Lineamientos de un proceso penal, cit. (n. 12), p. 87. 
explicativa ante los Tribunales, los que decidirán si "fue o no probada" en juicio ${ }^{48}$, con un claro acercamiento en esto al proceso civil ${ }^{49}$.

Como señala con acierto Hassemer, "si se mira el concepto de verdad procesal bajo el punto de vista del derecho constitucional, se advierte que los límites en la búsqueda de la verdad material no son de lamentar, sino que se les debe dar la bienvenida", ${ }^{50}$ y por ello, la limitación para establecer en la sentencia la verdad material de lo ocurrido que conlleva el estricto apego al principio acusatorio, no constituye sino una más de las tantas necesarias y "bienvenidas" trabas que el sistema de justicia criminal impone a dicho ideal cuando predominan otros principios o intereses ${ }^{51}$.

\section{El Ministerio público como organismo autónomo y co-director de política} criminal.

El Ministerio Público, entendido como "aquella estructura de agentes públicos que, cualquiera sea su concreta denominación en cada ordenamiento, tiene por cometido específico el ejercicio de la acción penal en nombre del Estado" 52 , es un desarrollo contemporáneo, un oficio público posterior a la transformación de la inquisición histórica e, inclusive, a las

${ }^{48} \mathrm{Cfr}$. Hoyos de la Barrera, María Teresa, Principios fundamentales del nuevo proceso penal, en Revista de Derecho Procesal, 20 (2005), p. 51.

${ }^{49} \mathrm{El}$ Código Procesal Penal se aleja claramente de sus fuentes en esta materia, pues no impone ni permite al Tribunal un "deber judicial de esclarecimiento", y en consecuencia no autoriza al Tribunal la realización de diligencias de prueba motu proprio, a diferencia de la legislación procesal penal alemana, por ejemplo ( $\$ 155.2$ y 244.2$)$ véase: Амвоs, El proceso penal alemán, cit. (n. 24), p. 35, quien concluye que en el sistema alemán "a la Fiscalía y al tribunal les incumbe la carga de la prueba".

${ }^{50}$ Hassemer, Lineamientos de un proceso penal, cit. (n. 12), p. 86.

${ }^{51}$ Será ineludible en investigaciones venideras indagar cómo se ha hecho frente, o se deberá hacer, ante los desajustes que plantea un sistema binario, donde por un lado el Ministerio Público tenga espacios para limitar discrecionalmente el objeto de la acusación, y por otro, el tribunal deba ajustarse a ese objeto y a la pena mínima legalmente asignada a éste. Ello, por cuanto dicho sistema ya ha sido "probado" en el sistema federal estadounidense, donde luego de la promulgación de la "Sentencing Guideline" en noviembre de 1987, con la que se estableció para los jueces una pena mínima obligatoria para ciertos crímenes, en la práctica se incrementó la discrecionalidad y el poder de negociación de la Fiscalía frente a los defendidos - para quienes ejercer su derecho a juicio pasó a ser un riesgo muy alto-. Sin embargo, posteriormente la Corte Suprema de Estados Unidos resolvió en "Booker v. United States," 543 U.S. 220 (2005), que las "Sentencing Guideline” sólo serian "advisory” para los jueces; véase: Whiting, Alex. How Prosecutors Should Exercise Their Discretion Now that the Sentencing Guideline are Advisory [en línea] Issues in Legal Scholarship. 8 (2) artículo 2 <http://www.bepress. com/ils/vol8/iss2/art2> [consulta: 22 julio 2010].

${ }^{52}$ Díez-Picazo, El poder de acusar, cit. (n. 3), p. 12. 
propias ideas del iluminismo, el cual, no puede haber duda, tiene carta de ciudadanía francesa ${ }^{53}$.

Desde entonces, al Ministerio Público, por cierto con matices según los diversos ordenamientos en vista, se han ido delegando por el Estado diversas funciones, amén de su esencial actividad acusatoria, la de investigar los delitos, la dirección de las policías, e incluso, como es nuestro caso, la gestión y dirección de parte de la política criminal del Estado. Esta evolución va acompañada de la concesión de mayor o menor autonomía en el ejercicio de dichas responsabilidades, ya sea del Ejecutivo o del Poder Judicial, y en nuestro caso -alejándonos de los países más representativos tanto del "Common law" como del "Civil law"- de completa autonomía constitucional ${ }^{54}$.

Como parte del privilegiado acopio de funciones y autonomía de que goza el Ministerio Público chileno, se le ha dispensado un mayor margen de libertad para el ejercicio de la acción penal, y concretamente, para la formulación de la acusación ${ }^{55}$. Ello, en coherencia con el rol que la Fiscalía desempeña en nuestro ordenamiento como director e impulsor autónomo de "política criminal" del Estado ${ }^{56}$, si entendemos por tal "el conjunto de

${ }^{53}$ MaIER, El ministerio público, cit. (n. 42), p. 29.

${ }^{54} \mathrm{La}$ Corte Interamericana de Derechos Humanos, en el caso "Tristán Donoso vs. Panamá", de 27 de enero de 2009, reconoce la facultad de los Estados para organizar la función, estructura y ubicación institucional del Ministerio Público, considerando sus necesidades y condiciones particulares, pero siempre que con ello se cumpla con los propósitos y obligaciones determinadas en la Convención Americana, destacando que "el principio de legalidad de la función pública, que gobierna la actuación de los funcionarios del Ministerio Público, obliga a que su labor en el ejercicio de sus cargos se realice con fundamentos normativos definidos en la Constitución y las leyes. De tal modo, los fiscales deben velar por la correcta aplicación del derecho y la búsqueda de la verdad de los hechos sucedidos, actuando con profesionalismo, buena fe, lealtad procesal, considerando tanto elementos que permitan acreditar el delito y la participación del imputado en dicho acto, como también los que puedan excluir o atenuar la responsabilidad penal del imputado".

${ }^{55}$ El Tribunal Constitucional expresamente ha refrendado que la Reforma Procesal Penal atenúa el principio de legalidad procesal que regía en el antiguo sistema, otorgando al Ministerio Público "amplias facultades para dirigir la investigación y decidir sobre el curso de la misma, facultades en las cuales puede actuar con cierta discrecionalidad".: sentencia rol $\mathrm{N}^{\circ} 1.341-2009$, de 15 de abril de 2010.

${ }^{56}$ La Fiscalía Nacional ha sostenido una opinión diversa, en su Instructivo General No 35, de 15 de diciembre de 2000, al señalar en relación al principio de oportunidad que "no se trata de politicas públicas de persecución criminal, para enfrentar el fenómeno de la criminalidad, función que excede a la labor de este Organismo" La función del principio de oportunidad como herramienta de política criminal es reconocida entre otros, por Horvitz - López, Derecho procesal penal chileno, cit. (n. 17), I, p. 448; y HasSEMER, Winfried, La persecución penal: legalidad y oportunidad (traducción de Miguel A. Cobos Gómez de Linares), en Jueces para la democracia, 4 (1988), p. 9. 
criterios determinantes de una lucha eficaz contra el delito" ${ }^{57}$.

$\mathrm{Al}$ respecto, Matus Acuña estima que aunque evidentemente la política nacional de persecución penal corresponda a diversos organismos del Estado, y entre ellos, en primer lugar a los órganos colegisladores, a través de la formulación de los delitos y sus penas, la forma como el fiscal nacional regula autónomamente cuándo y cómo se ejercerá la acción en cada caso es la forma como se concreta esa política de persecución penal del Estado ${ }^{58}$. Es más, agrega el autor citado que, cuando los fiscales toman decisiones propias de su actividad, como cuándo acceder a un procedimiento abreviado, en los hechos, todos los días y todos los fiscales adjuntos del Ministerio Público están tomando decisiones de política criminal, esto es, decisiones que hacen realidad la política de persecución penal del Ministerio Público y que suponen la existencia de criterios sobre cuáles delitos se estima prioritario perseguir, con todo el rigor de la ley, y cuáles no ${ }^{59}$. De ese modo, "los objetivos finales que guíen al sistema en su totalidad y a la elaboración de cada una de las instituciones jurídicas deben ser, entonces, de tipo político-criminal"60.

Al gestionar e impulsar su política criminal, el Ministerio Público no puede pasar por alto el fin de prevención especial de las penas que persigue, y para alcanzar esto se le ha otorgado el principio de oportunidad como remedo o contrapeso a los excesos en que generalmente se incurriría de seguir ciegamente los principios de legalidad y de retribución. Ahora bien,

${ }^{57}$ Von Liszt, Franz, citado por Silva SÁnChEZ, Jesús-María, Reflexiones sobre las bases de la política criminal. En El mismo, Politica criminal y persona (Buenos Aires, Ad hoc, 2000), p. 15.

${ }^{58}$ Matus Acuña, Jean-Pierre, Criterios de actuación del Ministerio Público en materias penales, en recensión a "Reforma procesal penal. Oficios del fiscal nacional. Materias penales. 2001-2004”, en Ius et Praxis, 12 (2006) 1, pp. 305-313.

${ }^{59}$ Matus Acuña, Jean-Pierre, El Ministerio Público y la política criminal en una sociedad democrática, en Revista de Derecho, 19 (Valdivia, 2006) 2, pp. 187-203. Será necesario abordar en el futuro la dicotomía que esta plena autonomía genera, pues los fiscales, en cualquier grado de su jerarquía, pese a estar a cargo de la dirección de políticas públicas como hemos explicado, no responden de su gestión política a la comunidad, por no pertenecer orgánicamente al Ejecutivo, a un gobierno que responda a un parlamento, ni ser elegidos por referendo. En similar sentido, Soto PiñeIro, Miguel, El principio de la discrecionalidad en el nuevo sistema penal, en Revista de Derecho de la Universidad Finis Terrae, año VI, 6 (2002), pp. 167-170; y Armenta Deu, Teresa, Principio acusatorio y derecho penal (Barcelona, Bosch, 1995), pp. 43 y 44, para quien sólo en sociedades que cuentan con elección democrática como elemento de control de los perseguidores públicos, es plausible la aplicación a la persecución penal de criterios de oportunidad y la concesión de un mayor ámbito de facultades.

${ }^{60}$ Roxin, Claus, Politica criminal y dogmática penal hoy en día, en EL Mismo, La teoría del delito en la discusión actual (traducción de. Manuel Abanto V., Lima, Grijley, 2007), p. 42. 
como explicaremos en el apartado siguiente, la posibilidad de modificar la acusación conforme al artículo 407 CPP., como actualización del principio de oportunidad, es precisamente una manifestación de la política criminal que desempeña autónomamente el Ministerio Público.

Hoy en día, sin embargo, pareciera existir una percepción ciudadana contraria de la función del Ministerio Público, ligada exclusivamente a la persecución y a la retribución, y es por ello, que de vez en cuando, es necesario traer a la memoria los fines que motivaron el nacimiento de las instituciones, y en el caso del Ministerio Público, que éste es una privilegiada herencia del Iluminismo, en el cual "cobró vida como medio de liberación ciudadana y no como instrumento de represión autoritaria"61.

Emergerá frente a lo dicho hasta aquí un plausible temor a que el actuar de cada fiscal responda a criterios personales y circunstanciales, y no a una política criminal general que garantice un trato igualitario a los imputados que se encuentren en iguales circunstancias ${ }^{62}$. Pero este temor puede disiparse, y así lo sostendremos en la investigación, con la uniformización y formalización de criterios a través de instructivos generales emitidos por la autoridad máxima del Ministerio Público y el control jerárquico interno por las propias autoridades de dicha institución ${ }^{63}$. Es precisamente en el ejercicio del principio de oportunidad, uno de los ámbitos en que a juicio de Roxin puede imponerse legítimamente una vinculación a un fiscal por su superior jerárquico a través de instrucciones, y ello, porque aquí no se trata de un problema jurídico, sino de un problema político-jurídico ${ }^{64}$.

Esta uniformización y control administrativo aportaría seguridad y certidumbre jurídica, así como publicidad y transparencia sobre las políticas criminales que desarrolle el Ministerio Público ${ }^{65}$ (tipo de casos en que se

${ }^{61}$ Roxin, Posición jurídica y tareas futuras, cit. (n. 42), p. 39.

${ }^{62} \mathrm{Al}$ respecto, DíEZ-PICAzo, El poder de acusar, cit. (n. 3), p. 20, indica que quienes se oponen a la discrecionalidad en el ejercicio de la acción penal, han recurrido al "argumento de la objetividad de la justicia", el que introduce consideraciones relativas al principio de igualdad ante la ley, con los que se busca "evitar un trato discriminatorio entre ciudadanos que se hayan en circunstancias jurídicamente similares”. PECCHI, El procedimiento abreviado, cit. (n. 22), p. 133, por su parte, manifiesta el temor que, dependiendo la procedencia y los términos del procedimiento de la voluntad de cada fiscal, va a ser difícil lograr una relativa uniformidad entre los numerosos fiscales existentes a lo largo del país.

${ }^{63}$ Actividades autorizadas por los artículos 7 y 17 letra a) de la Ley $N^{\circ}$ 19.640: Orgánica constitucional del Ministerio Público.

${ }^{64}$ Roxin, Posición jurídica y tareas futuras, cit. (n. 42), pp. 44-46.

${ }^{65}$ Como sostiene Jean-Pierre, Acuña, Criterios de actuación del ministerio público: "lo verdaderamente importante en este aspecto es que al expresarse tales políticas en instrucciones de política general, pueda esperarse que ellas sean ejecutadas unifor- 
podrá dar esta modificación de cargos, y límites de ésta), lo que posibilita igualmente su escrutinio ciudadano, y la proscripción administrativa de las prácticas inadecuadas que pueden germinar por esta discrecionalidad.

Sin embargo, y paradójicamente, pese a que, como ha denunciado últimamente la doctrina, los fiscales modifican a diario sus acusaciones en la forma que venimos comentando ${ }^{66}$, la autoridad máxima del propio Ministerio Público uniforme y reiteradamente ha desestimado absolutamente la alteración de cargos en la acusación, instruyendo a los fiscales -sin éxito por cierto- que "se atengan estrictamente al mérito de la investigación y no modifiquen su acusación por delitos de menor penalidad, con el objeto de llegar a un procedimiento de esta naturaleza, pues ello es contrario al principio de legalidad" ${ }^{67}$, olvidando pareciera, la existencia del principio de oportunidad, y cómo estos principios se conectan e influyen recíprocamente, desconociendo que integrante fundamental de un sistema de consecuencias jurídicas es el elemento de carácter fáctico determinado por la propia praxis de los jueces y tribunales en su aplicación ${ }^{68}$, y en fin, no percatándose que esa falta de regulación administrativa, no logra más que dejar la modificación de la acusación a la mera discreción personal del fiscal, sin ningún parámetro objetivo y general propio de una política criminal que respete el principio de igualdad entre los justiciables, y en definitiva, como agudamente advierte Rusconi, la opción ya deja de ser disponibilidad o no disponibilidad, "sino disponibilidad caótica o regulada" ${ }^{\prime 9}$.

Finalmente, no está de sobra aclarar que coincidimos con Hassemer ${ }^{70}$ en que el principio de oportunidad transmite -sobre todo cuando sus presupuestos de aplicación no están estrictamente definidos- una impresión de "desigualdad, inconsecuencia y desilusión", y por ello igualmente, nos sumamos a la aspiración de De Diego Díez, por una taxativa regulación legal del beneficio que se concederá a aquél que se someta al procedimiento

memente por los fiscales adjuntos de todo el país, de manera que [...] la decisión estratégica que se adopte no esté gobernada por el humor o por el lugar donde se encuentre el fiscal adjunto de turno, sino por criterios de igual aplicación en todo el país."

${ }^{66}$ Para una exposición sistematizada de este tipo de casos en nuestra jurisprudencia, véase: Del Río, Proceso penal, cit. (n. 22), pp. 77 ss.

${ }^{67}$ Oficio de la Fiscalía Nacional No 286/2010, de 31 de mayo de 2010, que unifica y reitera el criterio manifestado en oficios anteriores dictados desde el año 2001, los cuales deja sin efecto.

${ }^{68}$ Silva Sánchez, Jesús-María. ¿Política criminal del legislador, del juez, de la administración penitenciaria? Sobre el sistema de sanciones del Código Penal español, en EL mismo, Politica criminal y persona (Buenos Aires, Ad hoc, 2000), p. 113.

${ }^{69}$ Rusconi, Maximiliano, Imputación, tipo y tipicidad conglobante (Buenos Aires, Ad Hoc, 2005), p. 60.

${ }^{70}$ Hassemer, La persecución penal, cit. (n. 12), p. 9. 
abreviado -o se "conforma" en el procedimiento español-, de tal suerte que, aceptando ello, se produjera siempre una minoración preestablecida de la pena, y ello no responda a una contraprestación negociada por el fiscal o acusador, ni sea dejado tampoco al criterio dispar del arbitrio judicial en cada caso $^{71}$. Sólo se busca entonces constatar que una uniformización efectuada desde el interior del propio Ministerio Público, adecuadamente ejecutada y supervisada, puede ya satisfacer las exigencias de igualdad, y además, que la uniformización administrativa en todo caso, siempre será necesaria ante la natural imposibilidad del legislador de regular todas las situaciones posibles en que la modificación de la acusación parezca aconsejable ${ }^{72}$. Es por esto último que un tratamiento penal de este asunto, que sólo consista en la modificación legislativa de las sanciones que aparezcan como desproporcionadas frente al conjunto de nuestro ordenamiento penal, resultará insuficiente, y mientras no haya una íntegra solución sustantiva, se mantendrá necesario el tratamiento procesal de estos problemas.

\section{El principio de oportunidad y su relación con los fines preventivos de la} pena.

El principio de oportunidad ha sido objeto de profundas reflexiones y constantes debates doctrinales en los últimos años, especialmente en el ámbito europeo a partir de la $1^{\text {a }}$ Guerra Mundial, incorporándose en mayor o menor medida a diferentes ordenamientos jurídicos de dicho ámbito ${ }^{73}$.

El concepto de este principio parte de su contraposición al de legalidad (también conocido como de obligatoriedad, irretractabilidad o irrevocabilidad de la acción penal), por tanto, si este último significa que el órgano de la acusación está obligado a ejercitar la acción por todo hecho que revista caracteres de delito conforme a la ley, el de oportunidad debe referirse a cualquier excepción a esta obligación ${ }^{74}$.

${ }^{71}$ De Diego Díez, La conformidad del acusado, cit. (n. 9), p. 238. El Mensaje de la Ley $\mathrm{N}^{\circ} 20.074$, que sustituyó el artículo 407 CPP., contenía una rebaja de hasta un grado de la pena en caso de aceptación de los hechos, lo cual fue eliminado durante su tramitación en el Senado. Pfeffer Ureuiaga, Emilio, Código Procesal Penal. Anotado y concordado (2a edición, Santiago, Editorial Jurídica de Chile, 2006), pp. 407-408.

${ }^{72}$ Riess, P., citado por Armenta Deu, Criminalidad de bagatela, cit. (n. 1), p. 61, entiende que en cuanto al contenido y límites al principio de legalidad y de los casos de no persecución, es función importante del legislador establecer unos y otros, pero reconoce que no debe confiarse en exceso en su incapacidad de error, por lo que el intérprete deberá llevar a cabo, en algunas ocasiones, una función complementaria.

${ }^{73}$ Berzosa Francos, María Victoria, Los principios de legalidad y oportunidad en el proceso penal, en Picó Junoy, Joan (director), Problemas actuales de la justicia penal (Barcelona, JMB, 2001), pp. 13-14.

${ }^{74}$ Berzosa, Los principios de legalidad, cit. (n. 73), p. 15. Para una síntesis de las 
Si bien, la razón inicial de su incorporación se halló en argumentos económicos, como la necesidad de hacer frente al aumento de la pequeña y mediana criminalidad, considerada causa esencial del colapso de la administración de justicia, consiguiendo a su vez o a tal fin, abreviar o agilizar el proceso penal, lo cierto es que su consagración significó alejarse - sin llegar a abandonarlade la concepción retributiva de la pena, de la cual el principio de legalidad no es más que su herramienta ${ }^{75}$, y de ese modo, hoy los diferentes institutos procesales a través de los cuales se manifiesta el principio de oportunidad permiten no sólo descongestionar el sistema judicial sino también orientar la persecución penal por medio de la política criminal que fije el Ministerio Público $^{76}$, política dentro de la cual debe ocupar un lugar privilegiado los fines de prevención especial de la pena ${ }^{77}$.

Esta visión del principio de oportunidad supone desligarnos por cierto de la imagen tradicional que lo ata sólo a la llamada "criminalidad de bagatela", tratada en nuestro ordenamiento en el artículo 170 CPP., y entendida por la inmensa mayoría de la doctrina como "hechos contemplados en las leyes penales, cuya reprochabilidad es escasa y cuyo bien jurídico protegido se considera de menor relevancia"78.

Así visto el principio de oportunidad, la modificación de la acusación que permite el artículo $407 \mathrm{CPP}$, puede ser considerado como una más de las excepciones que nuestro legislador hizo al principio de legalidad, al consagrar un modelo de oportunidad reglada o discrecionalidad restringida ${ }^{79}$, en

razones a favor de los principios de legalidad y de oportunidad, véase: HASSEMER, $L a$ persecución penal, cit. (n. 12), p. 8-11.

${ }^{75} \mathrm{La}$ mayoría de los autores de comienzo del siglo XX entiende que el principio de legalidad es correlato imprescindible de la teoría absoluta del derecho penal, derivado como consecuencia necesaria de la amenaza penal estatal. Armenta Deu, Criminalidad de bagatela, cit. (n. 1), p. 58.

${ }^{76}$ Como expone Armenta Deu, Criminalidad de bagatela, cit. (n. 1), p. 231, un determinado sector de la doctrina continental considera beneficioso el uso del p. de oportunidad como complemento -desde la perspectiva político-criminal- de una tendencia del derecho penal hacia la mínima intervención. En una posición diversa, RuIZ VADILlo, Enrique, El principio de oportunidad reglada, en El mismo, Estudios de Derecho procesal penal (Granada, Comares, 1995), p. 38, para quien el principio de oportunidad ha nacido "no para perfeccionar humana o técnicamente la justicia penal", sino sólo para descongestionar el sistema penal.

${ }^{77}$ DíEz-PiCAzo, El poder de acusar, cit. (n. 3), p. 30, precisamente constata que los ordenamientos que se inspiran en la idea de discrecionalidad, dada la flexibilidad que ésta imprime en la acción penal, están en sintonía con aquellas construcciones teóricas que atribuyen a la sanción penal una finalidad de disuasión, en el plano individual, y de prevención, en el plano colectivo.

${ }^{78}$ Armenta Deu, Criminalidad de bagatela, cit. (n. 1), p. 23.

${ }^{79}$ Así califica el modelo actual DucE, Mauricio, Selección de casos en el nuevo Código 
contraposición al modelo de legalidad absoluta existente en nuestro sistema hasta antes de la reforma ${ }^{80}$.

Todas estas decisiones en el ejercicio del principio de oportunidad se encuadran en la política criminal del Ministerio Público, que como parte de un Estado de Derecho, no puede desatender entre los elementos limitadores de la pena a la culpabilidad y a su finalidad de prevención especial ${ }^{81}$, y por tanto estos deben estar presentes al ejercer el principio de oportunidad, y en particular, en la manifestación de éste que nos interesa: la modificación de la acusación conforme al artículo 407 CPP. .

Viene aquí a colación el subprincipio de "considerar las hipotéticas consecuencias de la incriminación”, que es una expresión más concreta del principio de la necesidad de la pena como límite normativo material del ius puniendi, por el cual, en la incriminación secundaria -al momento de la aplicación de la norma- en disposición del principio de oportunidad, el Ministerio Público no sólo puede renunciar al ejercicio de la acción penal cuando las consecuencias de la aplicación de la ley puedan producir más perjuicios que beneficios ${ }^{82}$, sino también morigerar el rigor del marco penal abstracto $^{83}$.

Procesal Penal, en Revista Chilena de Derecho, 29 (2002) 2), p. 261.

${ }^{80}$ En el mismo sentido, HoRwitz Lennon, María Inés, Algunas formas de acuerdo o negociación en el proceso penal: tendencias del Derecho penal comparado, en Revista de Ciencias Penales, 40 (1994) 2, p. 30, sostiene que la libertad de discrecionalidad en la formulación de la acusación -aun cuando existan fundadas sospechas de que el inculpado cometió un hecho punible- constituye una manifestación del denominado principio de oportunidad, y en virtud de él se hace depender la persecución penal en consideraciones de convivencia, especialmente de carácter político y económico.

${ }^{81} \mathrm{El}$ neo-proporcionalismo, al contrario, aboga porque los factores preventivoinstrumentales, especialmente la prevención especial, sólo pueden operar en el marco de la determinación de la pena en sentido amplio, es decir, no determinan la pena adecuada al injusto culpable sino sus posibilidades de sustitución o suspensión. FEIJOO SÁnCHEz, Bernardo, Individualización de la pena y teoría de la pena proporcional al hecho, [en línea] InDret 1 (2007), http://www.indret.com/pdf/403_es_1.pdf [consulta: 22 julio 2010].

${ }^{82}$ Bustos Ramírez, Juan - Hormazábal Malarée, Hernán, Nuevo sistema de derecho penal (Madrid, Trotta, 2004), pp. 26 ss.

${ }^{83}$ En el sistema norteamericano, se defiende la discrecionalidad -no así la arbitrariedad- en el proceso de formulación de cargos, así como en el de la determinación de la pena, por permitir ello, al considerar las circunstancias y hechos de cada caso individual, lograr un razonable y justo resultado. Véase: DAvis, Arbitrary Justice, cit. (n. 16), p. 165. Bustos ha ido más lejos aún al indicar que en relación a la necesidad de la pena, parece adecuado que quede establecido el máximo de la pena y no el mínimo, ya que desde una perspectiva político-criminal podría ser aconsejable no imponer pena alguna, no ser ésta necesaria, o bien, implicar un daño grave a la persona. Bustos - HormazÁBAL, Nuevo sistema de derecho penal, cit. (n. 82), p. 135. La inexistencia de un mínimo 
Adquiere entonces aquí su merecido protagonismo la formalización del derecho penal, esto es, el de su ejercicio controlado, no sólo mediante técnicas de protección, sino también mediante la observancia de ciertos principios valorativos que en su conjunto buscan evitar que el control social jurídicopenal imponga lesiones jurídicas innecesarias ${ }^{84}$.

Esta especial preocupación por el fin de prevención especial de las penas, no conlleva desentendernos de su finalidad de prevención general, sino asimilar que "el derecho penal no sólo tiene como fin el de prevenir delitos o reacciones informales de la sociedad, sino también el de reducir en la mayor medida posible su propia intervención", de manera que "si el establecimiento de una pena menos grave o incluso la despenalización de determinadas conductas no redundan en una menor eficacia preventiva, debe procederse a ello sin mayores dilaciones" 85 .

La estrecha relación entre el derecho penal y procesal penal que secundamos, como ha podido advertirse, no supone un cambio de las funciones que de antaño la doctrina atribuye a la sanción penal ${ }^{86}$, sino que, reconociendo

para las penas -aun cuando no constituye el objeto de nuestra propuesta, abogando por ahora sólo por una moderada flexibilización de los marcos punitivos abstractos-, no debiera a estas alturas resultarnos tan perturbador ni inquietante, si advertimos que la Corte Suprema así ya lo ha resuelto en el marco de la Ley $\mathrm{N}^{\circ} 20.084$, en fallo de $14 \mathrm{de}$ julio de 2008, rol Corte $\mathrm{N}^{\circ} 316-2008$.

${ }^{84}$ Sobre este concepto, se sigue en esta parte a Hassemer, Winfried - Muñoz Conde, Francisco. Introducción a la Criminología y al Derecho Penal (Valencia, Tirant Lo Blanch, 1989), pp. 118 ss.

${ }^{85}$ Silva SÁnchez, Jesús María, Aproximación al derecho penal contemporáneo (Barcelona, Bosch, 1992, reimpresión 2002), pp. 242-243. El mismo autor, en el mismo sentido, pero aunado al análisis económico del derecho, véase: Eficiencia y Derecho Penal, en El mismo, Política criminal y persona (Buenos Aires, Ad Hoc, 2000), pp. 3388. Parece este autor haber dado un giro en su artículo: La teoría de la determinación de la pena como sistema (dogmático): un primer esbozo. [en línea] InDret, 2 (2007) http://www.indret.com/pdf/426_es.pdf [consulta: 22 julio 2010], donde sostiene que la política criminal que hace el juez en la individualización de la pena no debe efectuarse directamente, sino que la teoría de la determinación de la pena debe manifestarse, ante todo, como la dimensión cuantitativa de un sistema de la teoría del delito.

${ }^{86}$ Por cierto, la proximidad de la limitación consensuada del hecho de cargo, al proceso civil, como resultado de la nueva orgánica del proceso penal y su carácter acusatorio y contradictorio, no compromete la naturaleza y finalidad pública de la pena o ius puniendi, las que precisamente fundamentan un rechazo a reducciones abusivas o arbitrarias por parte del Fiscal, y que además deben encuadrarse en la política criminal del Estado. En ese orden, Armenta Deu, Criminalidad de bagatela, cit. (n. 1), p. 237. Sin embargo, el margen con que se admita la posibilidad de disponer indirectamente sobre el derecho material penal, tendrá relevancia al decidir la calificación que debe atribuirse a la decisión del acusado de someterse al procedimiento abreviado, ya sea como allanamiento, convenio, o acto de disposición procesal. 
que el fin que en definitiva se le atribuya obedece a una política criminal adoptada por el Estado, ella no debe posponerse a las etapas de individualización judicial o ejecución de la pena, donde su incidencia es residual, sino que debe ya orientar las decisiones y actuaciones previas de todos los intervinientes del proceso, entre ellas, la modificación de la acusación conforme al artículo 407 CPP. como parte del proceso de consenso llevado a cabo por el Ministerio Público con el imputado ${ }^{87}$. Sin embargo, no podemos soslayar cómo nuestra proposición pone en peligro los logros que conlleva la estricta sujeción al principio de legalidad, entre los que la doctrina ha destacado, el efecto conminatorio de la sanción penal o la pérdida de credibilidad del sistema desde la perspectiva de la prevención general ${ }^{88}$.

Antes de finalizar este apartado, conviene admitir que quedará como objeto pendiente de estudio, el dilucidar cómo lo aquí propuesto, cuando la sanción consensuada entre el fiscal y el acusado y su defensa no se avienen con la retribución perseguida por la víctima ${ }^{89}$, se concilia con el derecho de ésta a ser oído en juicio y a la tutela judicial efectiva ${ }^{90}$ o derecho a la ju-

${ }^{87}$ Esta lógica, que podríamos denominar de "anticipación”, ya inspiró otras instituciones novedosas de la Reforma Procesal, como la suspensión condicional del procedimiento, sobre la que se señaló en la Cámara de Diputados que consiste, fundamentalmente, en una anticipación del tipo de solución que la sentencia otorgará al caso, evitando los efectos estigmatizantes del procedimiento y la eventual prisión preventiva para quien, finalmente, se hará acreedor a una medida no privativa de libertad destinada a su reinserción social de la Ley $\mathrm{N}^{\circ}$ 18.216. Pfeffer, Código Procesal Penal, cit. (n. 71), pp. 371-372.

${ }^{88}$ Cfr. Armenta Deu, Criminalidad de bagatela, cit. (n. 1), pp. 196-197.

${ }^{89}$ Como ya se habrá reparado, nuestro ordenamiento adjetivo se aleja de su modelo alemán, el que reserva el monopolio de la acción penal al Fiscal, y en ese orden, el Tribunal Constitucional ha resuelto que el ejercicio de la acción penal pública del Ministerio Público no es de carácter monopólico o exclusivo, sino preferente, y es un derecho autónomo que también le corresponde a la víctima (sentencia rol $N^{\circ} 815-2007$ de 19 de agosto de 2008), agregando posteriormente, que "las facultades investigativas privativas del Ministerio Público, si bien son discrecionales, incluyen elementos reglados $y$, además, deben entenderse en armonía con los derechos del afectado, quien puede ejercer un conjunto de prerrogativas tendientes a obtener la tutela jurisdiccional efectiva de sus intereses" (sentencia rol $\mathrm{N}^{\circ} 1.349-2009$ de 13 de julio de 2010). Y a igual conclusión arriban Horvitz - López, Derecho procesal penal chileno, cit. (n. 17), I, p. 289, al señalar que la actual normativa constitucional confiere a la víctima la calidad de titular del derecho constitucional al ejercicio de la acción penal en los mismos términos del ministerio público.

${ }^{90}$ Entendido como "aquel (derecho) que tiene toda persona a obtener tutela efectiva de sus derechos e intereses legítimos ante el juez ordinario predeterminado por la ley y a través de un proceso con todas las garantías, sin dilaciones indebidas y en el que no se produzca indefensión", según Cámara Villar, Gregorio, en Balaguer CalleJón, Francisco (coordinador), Manual de Derecho constitucional ( 5 a edición, Madrid, 
risdicción (artículo $8 \mathrm{~N}^{\circ} 1$ y $25 \mathrm{~N}^{\circ} 1$ Convención Americana de Derechos Humanos ${ }^{91}$, artículo $14 \mathrm{~N}^{\circ} 1$ del Pacto Internacional de Derechos Civiles y Políticos, artículo 8 Declaración Universal de Derechos Humanos, así como

Tecnos, 2010), II, p. 215. Para un examen del reconocimiento de dicho derecho en el nuevo ordenamiento procesal, véase la sentencia del Tribunal Constitucional, rol $\mathrm{N}^{\circ}$ 815-2007, de 19 de agosto de 2008, que declaró inaplicable el artículo 230 CPP. BoRDalí Salamanca, Andrés, No hay ejercicio del derecho fundamental de acción en el proceso penal, en Revista de Derecho, 21 (2008) 2, pp. 247 ss., previene que aun cuando todos los ciudadanos puedan incoar la persecución penal, ello no debe comportar una concepción privatista del proceso penal, el cual sigue siendo un asunto de interés público, y por tanto, en realidad la víctima no tiene un derecho fundamental de acción, sino más bien se le asegura una actividad que supone la activación de la investigación penal mediante la respectiva querella y luego la posibilidad de acusar. De manera diversa, CAFFERATA NORES, José, ¿La pena al culpable es un derecho de la víctima por ser parte de su reparación? en EL MISMO, Cuestiones actuales sobre el proceso penal ( $3^{\text {a }}$ edición, Buenos Aires, Editores del Puerto., 2000), pp. 66-67, conjetura que el derecho del ofendido a obtener la aplicación de la pena prevista en la ley para el caso de vulneración de un bien jurídico abstracto, se justifica en que el derecho penal no sólo tiene por fin la tutela subsidiaria de los intereses generales de la sociedad penalmente simbolizados en los bienes jurídicos, sino también debe tutelar los intereses concretos de la víctima, y en condiciones de igualdad. La doctrina constitucional española ha desarrollado con especial interés los alcances de este derecho, impulsada por su expresa consagración en el artículo 24 de su Constitución de 1978, sin perjuicio de además encontrarse consagrado en instrumentos regionales como la Declaración de los derechos y libertades fundamentales del Parlamento Europeo (artículo 19,1) y en la Convención europea de derechos humanos (artículo 13), de ahí su abundante desarrollo por parte del Tribunal Constitucional español, véase: Sánchez Rubio, María Aquilina, Derecho a la tutela judicial efectiva: Probibición de sufrir indefensión y su tratamiento por el Tribunal Constitucional, en Anuario de la Facultad de Derecho. 21 (2003), pp. 601-616, (http://dialnet.unirioja. es/servlet/articulo?codigo $=854367$ ) [consulta: 31 octubre 2010]. Es así como el Tribunal Constitucional español, en su sentencia 147/1985, de 29 de octubre, consideró aceptable incluir el ejercicio de la acción popular, en su régimen legal concreto, como parte integrante del derecho fundamental a recabar la tutela judicial efectiva, susceptible, por tanto, de fundamentar el recurso de amparo. De Diego DíEz, La conformidad del acusado, cit. (n. 9), nota 172.

${ }^{91}$ Los organismos regionales de protección de los derechos humanos han producido un conjunto de opiniones y decisiones sobre los alcances de este derecho, entre las que podemos citar el Informe $\mathrm{N}^{\circ} 29 / 92$, caso 10.029 y otros (1993), de la Comisión Interamericana de Derechos Humanos, donde ésta sostuvo que "en los sistemas que lo autorizan, el acceso a la jurisdicción de la victima de un delito deviene en un derecho fundamental del ciudadano y cobra particular importancia en tanto impulsor y dinamizador del proceso criminal"; y en el caso "Velásquez Rodríguez", de 29 de julio de 1988, la Corte Interamericana de Derechos Humanos resolvió que el Estado tiene el deber jurídico de "investigar seriamente con los medios a su alcance [...] las violaciones que se hayan cometido [...] a fin de identificar a los responsables" e "imponerles las sanciones pertinentes". 
los artículos $19 \mathrm{~N}^{\circ} 3$ y 83 inciso $2^{\circ}$ de la CPol., y a nivel meramente legal, los artículos 6 y 109 letra d) CPP.).

Desde ya podemos adelantar que las desavenencias que sobre el hecho atribuido o la pena perseguida se puedan producir, ya sea que provengan de un apego estricto al principio de legalidad y a los fines retributivos de la pena por parte del ofendido, o a que éste considere que una pena ajustada al injusto y culpabilidad del hecho concreto o a las necesidades de prevención especial son superiores a las requeridas por el acusador fiscal, en ambos casos nuestro codificador las resolvió a favor del derecho a la tutela judicial efectiva de la víctima-querellante, al facultarse a ésta ${ }^{92}$, primero, para oponerse al procedimiento abreviado, cuando la pena que a su juicio ameritan los hechos, es superior a los 5 años de presidio o reclusión, caso en el cual, si esta oposición es fundada, el juez deberá rechazar la solicitud de procedimiento abreviado, dictando el correspondiente auto de apertura ${ }^{93}$ (artículo 406 CPP.), y en segundo término para, dentro del procedimiento abreviado, solicitar una

${ }^{92}$ Siempre bajo el supuesto que los hechos objeto de acusación por la querellante fueron materia de formalización previa de la investigación, según se desprende de los artículos 261 letra a) y 413 en relación al 341, CPP., formalización que, según ha resuelto nuestro Tribunal Constitucional, puede ser forzada por el querellante, en virtud de una interpretación amplia del artículo 186 CPP., salvando de ese modo la traba mencionada. Cfr. Las sentencias del Tribunal Constitucional, rol $\mathrm{N}^{\circ} 1.337-09$, de 20 de agosto de 2009; rol No 1.467-2009, de 29 de diciembre de 2009; rol N 1.341-2009, de 15 de abril de 2010; rol $\mathrm{N}^{\circ} 1.380-2009$, de 3. De noviembre de 2009; rol $\mathrm{N}^{\circ} 1.542-09$, de 31 de agosto de 2010 y rol No 1.484-2009, de 5 de octubre de 2010. El ejercicio discrecional de la formalización, así como de todas las otras manifestaciones de discreción por parte del Ministerio Público a lo largo del proceso - principio de oportunidad de artículo 170 CPP., suspensión condicional del procedimiento, decisión de no perseverar, etc.-, requieren un estudio más amplio y extenso, que excede nuestro particular foco de interés (en lo que respecta a la formalización y suspensión condicional del procedimiento, véase la sentencia del Tribunal Constitucional rol $\mathrm{N}^{\circ} 1.445-2009$, de 29 de enero de 2010.

${ }^{93} \mathrm{Cfr}$. la sentencia de la Corte de Apelaciones de Santiago, rol N 997-2007, de 24 de mayo de 2007: "entiende esta Corte que el querellante, que es parte en este juicio, tiene derecho a intentar obtener, en el juicio oral respectivo, a lo menos la pena que la propia ley ha señalado para la infracción del artículo $397 N^{\circ} 1$ del Código Penal... pues como parte que es, tiene derecho a que sus planteamientos jurídicos sean analizados en el tribunal de juicio oral en lo penal, para eventualmente ver cumplida su pretensión de imposición de una pena superior a la que está pidiendo el Ministerio Público para el imputado de autos". 
pena superior a la pedida por el fiscal, quedando en este caso el Juez limitado sólo por la primera ${ }^{94}$ (artículo $\left.412 \mathrm{CPP}.\right)^{95}$.

Estas herramientas conferidas a la víctima-querellante, pueden ser vistas como un condicionamiento a la importación del principio de oportunidad en esta instancia procesal de negociación entre Ministerio Público e imputado, pues en principio parece que la "transacción" penal debiera transcurrir no sólo entre el Ministerio fiscal y el imputado, sino también con los demás acusadores privados ${ }^{96}$. Sin perjuicio de asumir tal cortapisa, creemos que en realidad estamos frente a una garantía de control sobre la actuación del fiscal, eliminando la sospecha o el peligro de arbitrariedad que podría significar en algún caso el monopolio del ejercicio de la acción penal ${ }^{97}$, todo ello, amén de constituir una afirmación del derecho a la tutela judicial efectiva por parte de la víctima.

${ }^{94}$ Cfr. las sentencias de la Corte de Apelaciones de Santiago, rol No $2.968-2007$, de 18 de diciembre de 2007 y rol $N^{\circ} 1.611-2009$, de 10 de septiembre de 2009. Nos aproximamos en esto al modelo del procedimiento abreviado español, en el cual, conforme al artículo 787,1. de la Ley de Enjuiciamiento Criminal, la defensa, con la conformidad del acusado presente, puede pedir al Juez o Tribunal que proceda a dictar sentencia de conformidad "con el escrito de acusación que contenga pena de mayor gravedad", sea éste el del Ministerio Fiscal o del acusador particular o público.

${ }^{95}$ Ambas facultades de la víctima-querellante, pueden considerarse como parte de los mecanismos que a juicio del Tribunal Constitucional, el Código Procesal Penal ha previsto "para el cumplimiento de las exigencias derivadas de la necesidad de garantizar una investigación "racional y justa". Enunciando dichos mecanismos, las sentencias del Tribunal Constitucional, rol $\mathrm{N}^{\circ} 1.244-2008$, de 2 de junio de 2009; rol $\mathrm{N}^{\circ}$ 1.445-2009, de 29 de enero de 2010 y, ratificando las anteriores, rol $N^{\circ} 1.349-2009$, de 13 de julio de 2010. Vale apuntar que tales mecanismos no están contemplados para el procedimiento simplificado de resolución inmediata del artículo 395 CPP., donde pareciera que el derecho a la tutela judicial efectiva se ve seriamente erosionado (este asunto fue llevado ante el Tribunal constitucional en causa rol $N^{\circ} 1.312-2009$, de 28 de enero de 2010, pero sin lograr un pronunciamiento sobre el fondo de la controversia).

${ }^{96}$ Así lo manifestó Gimeno Sendra, Vicente, Los procedimientos penales simplifcados (principio de "oportunidad" y proceso penal monitorio). [en línea] Poder Judicial, Extra 2 (1988), pp. 31-52 (ejemplar dedicado a: Justicia penal), http://dialnet.unirioja. es/servlet/articulo?codigo $=84034$ [consulta: 31 octubre 2010], en relación a la amplitud de acusadores que posibilita la acción popular consagrada por el ordenamiento español. En el mismo sentido, Armenta Deu, Criminalidad de bagatela, cit. (n. 1), p. 238. Berzosa, Los principios de legalidad, cit. (n. 73), p. 22, efectúa un diagnóstico más general y pesimista sobre la plena incorporación del principio de oportunidad en el sistema español, por entrar en contradicción con la acción popular y su reconocimiento en el artículo 125 de la Constitución española.

${ }^{97}$ Igual conclusión en De Diego Díez, La conformidad del acusado, cit. (n. 9), pp. 244-245; y Armenta Deu, Criminalidad de bagatela, cit. (n. 1), p. 238. 


\section{BiBLIOGRAFÍA}

Matus Acuña, Jean Pierre, Criterios de actuación del Ministerio Público en materias penales, en recensión a "Reforma procesal penal. Oficios del fiscal nacional. Materias penales. 2001-2004", en Ius et Praxis, 12 (2006) 1.

Aguilera, El principio del consenso. La conformidad en el proceso penal español (Barcelona, Cedecs, 1998).

Амвоs, Kai, Elproceso penal alemán y la reforma en América Latina (Santa Fe de Bogotá, Gustavo Ibáñez, 1998).

Амвоs, Kai, Estatus, función y responsabilidad del fiscal desde el punto de vista del Derecho comparado, en EL MISmo, Estudios del Derecho penal y procesal penal (Santiago, Editorial Jurídica de Chile, 2007).

Armenta Deu, Teresa, Criminalidad de bagatela y principio de oportunidad: Alemania y España (Barcelona, PPU, 1991)..

Armenta Deu, Teresa, Principio acusatorio y derecho penal (Barcelona, Bosch, 1995).

Barona Vilar, Silvia, La conformidad en el proceso penal (Valencia, Tirant lo Blanch, 1994).

Berzosa Francos, María Victoria, Los principios de legalidad y oportunidad en el proceso penal, en PIcó Junoy, Joan (director), Problemas actuales de la justicia penal (Barcelona, JMB, 2001).

Bordalí Salamanca, Andrés, No hay ejercicio del derecho fundamental de acción en el proceso penal, en Revista de Derecho, 21 (2008) 2.

Bustos Ramírez, Juan - Hormazábal Malarée, Hernán, Nuevo sistema de derecho penal (Madrid, Trotta, 2004).

Cabañas García, J. C., El proceso penal español ante una perspectiva de justicia penal negociad, en. Revista de Derecho Procesal, 2 (1991).

CAFFerata Nores, José, ¿La pena al culpable es un derecho de la víctima por ser parte de su reparación? en El MISMO, Cuestiones actuales sobre el proceso penal ( $3^{\text {a }}$ edición, Buenos Aires, Editores del Puerto, 2000).

Cámara Villar, Gregorio, en Balaguer Callejón, Francisco (coordinador), Manual de Derecho constitucional (5a edición, Madrid, Tecnos, 2010), II.

Cerda San Martín, Rodrigo - Hermosilla Iriarte, Francisco, El procedimiento abreviado (Nuevo sistema procesal penal) (Santiago, Metropolitana, 2003).

Colombo Cambell, Juan, Aspectos Constitucionales de la Reforma Procesal Penal, en Revista de Derecho Procesal, 20 (2005).

Conde-Pumido Ferreiro, Cándido, Elprincipio de legalidady el uso de la oportunidad reglada en el proceso penal, en Revista Poder Judicial, extra 6 (1989).

De Diego Díez, Luis Alfredo, El control judicial sobre la conformidad del acusado, en Revista Poder Judicial, 23.

De Diego Díez, Luis Alfredo, La conformidad del acusado (Valencia, Tirant lo Blanch, 1997.

De La Oliva Santos, Andrés, "Prólogo" a El"principio de consenso". La conformidad en el proceso penal español (Barcelona, Cedecs, 1998).

Del Río, Carlos, Proceso penal, consenso de las partes y enjuiciamiento jurisdiccional. Santiago, (Santiago, Librotecnia, 2009).

Díez-Picazo, Luis María, El poder de acusar. Ministerio Fiscal y constitucionalismo (Barcelona, Ariel, 2000). 
Duce, Mauricio, Selección de casos en el nuevo Código Procesal Penal, en Revista Chilena de Derecho, 29 (2002) 2).

Falcone, Diego, La absolución en el procedimiento abreviado, en Revista de Derecho de la Pontificia Universidad Católica de Valparaiso, 26 ( $1^{\mathrm{er}}$ semestre 2005).

Gimeno Sendra, Vicente, La nueva regulación de la conformidad (Ley Orgánica 7/1988), en Revista La Ley, 3 (1990).

GIMENO SENDRA, Vicente, Losprocedimientos penales simplificados (principio de "oportunidad" y proceso penal monitorio). [en línea] Poder Judicial, Extra 2 (1988), http:// dialnet.unirioja.es/servlet/articulo?codigo $=84034$.

Hassemer, Winfried - Muñoz Conde, Francisco. Introducción a la Criminología y al Derecho Penal (Valencia, Tirant Lo Blanch, 1989).

Hassemer, Winfried, La persecución penal: legalidad y oportunidad (traducción de Miguel A. Cobos Gómez de Linares), en Jueces para la democracia, 4 (1988).

Horvitz, María Inés - López, Julián.. Derecho procesal penal chileno (Santiago, Editorial Jurídica de Chile, 2005), II.

Horwitz Lennon, María Inés, Algunas formas de acuerdo o negociación en el proceso penal: tendencias del Derecho penal comparado, en Revista de Ciencias Penales, 40 (1994) 2.

Hoyos de la Barrera, María Teresa, Principios fundamentales del nuevo proceso penal, en Revista de Derecho Procesal, 20 (2005).

Langbein, John H., Tortura y “Plea Barganinig”, en MaIER, Julio - Bovino, Alberto (compiladores), El procedimiento abreviado (Buenos Aires, Editores del Puerto, 2001).

Langer, Máximo.) Revolución en el proceso penal latinoamericano: Difusión de ideas legales desde la periferia [en línea] Centro de Estudios de Justicia de las Américas. $<$ http://www.incipp.org.pe/modulos/documentos/descargar.php?id=273> [consulta: 22 de julio de 2010].

Matus Acuña, Jean Pierre, El Ministerio Público y la politica criminal en una sociedad democrática, en Revista de Derecho, 19 (Valdivia, 2006) 2.

Matus Acuña, Jean Pierre, La justicia penal consensuada en el nuevo Código de Procedimiento Penal, en Revista CREA, 1 (Universidad Católica de Temuco, 2000).

NúÑez Ávila, René, ¿Debe fallar el juez de garantía el procedimiento abreviado? en Revista Procesal Penal, 43 (LexisNexis, 2006).

Pecchi Croce, Carlos, El procedimiento abreviado en el nuevo Código Procesal Penal, en Revista de Actualidad Jurídica, 11 (enero 2005).

Pfeffer Urquiaga, Emilio, Código Procesal Penal. Anotado y concordado (2a edición, Santiago, Editorial Jurídica de Chile, 2006.

Riego Ramírez, Cristián, Elprocedimiento abreviado, en AA. VV., Nuevoprocesopenal (Santiago, Conosur, 2000).

Roxin, Claus, Culpabilidad y prevención en el Derecho penal (traducción de Francisco Muñoz, Madrid, Reus, 1981).

Roxin, Claus, Politica criminal y dogmática penal hoy en día, en EL MISmo, La teoría del delito en la discusión actual (traducción de. Manuel Abanto V., Lima, Grijley, 2007).

Roxin, Claus. Posición jurídica y tareas futuras del Ministerio Público, en MAIER, Julio B (compilador), El Ministerio Público en el proceso penal (Buenos Aires, Ad Hoc, 2000). 
Ruiz Vadillo, Enrique, El Derecho Penal en la encrucijada del año 2000, en El mismo, Estudios de Derecho procesal penal (Granada, Comares, 1995).

Ruiz VAdillo, Enrique, El principio de oportunidad reglada, en El mismo, Estudios de Derecho procesal penal (Granada, Comares, 1995).

Rusconi, Maximiliano, Imputación, tipo y tipicidad conglobante (Buenos Aires, Ad Hoc, 2005).

Salas Astrain, Jaime, Problemas del proceso penal (Santiago, Librotecnia, 2009).

SÁnchez Rubio, María Aquilina, Derecho a la tutela judicial efectiva: Probibición de sufrir indefensión y su tratamiento por el Tribunal Constitucional, en Anuario de la Facultad de Derecho. 21 (2003).

Shünemann, Bernd, Crisis del procedimiento penal (Marcha triunfal del procedimiento penal americano en el mundo), en Revista de Derecho Penal, 11.

SHünEmann, Bernd, Critica al Derecho penal de hoy (2a edición, $1^{\text {a }}$ reimpresión, Buenos Aires, Ad Hoc).

Silva SÁnchez, Jesús María, Aproximación al derechopenal contemporáneo (Barcelona, Bosch, 1992, reimpresión 2002).

Silva Sánchez, Jesús María, Eficiencia y Derecho Penal, en El mismo, Política criminal y persona (Buenos Aires, Ad Hoc, 2000).

Silva SÁnchez, Jesús-María, Reflexiones sobre las bases de la política criminal. En EL mismo, Politica criminal y persona (Buenos Aires, Ad hoc, 2000).

Silva SÁnChez, Jesús-María. ¿Politica criminal del legislador, del juez, de la administración penitenciaria? Sobre el sistema de sanciones del Código Penal español, en EL Mismo, Politica criminal y persona (Buenos Aires, Ad hoc, 2000).

Soto Piñeiro, Miguel, El principio de la discrecionalidad en el nuevo sistema penal, en Revista de Derecho de la Universidad Finis Terrae, año VI, 6 (2002).

Spataro, Armando, "Italia" en Maciá Gómez, Ramón (director), Sistemas deproceso penal en Europa (Barcelona, Cedecs, 1988).

Whiting, Alex. How Prosecutors Should Exercise Their Discretion Now that the Sentencing Guideline are Advisory [en línea] Issues in Legal Scholarship, 8, 2 artículo 2 <http://www.bepress.com/ils/vol8/iss2/art2> [consulta: 22 julio 2010]. 
